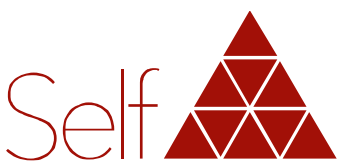

Revista do Instituto Junguiano de São Paulo

\title{
A psique expressiva: o estudo de um processo psicoterápico aliado à produção plástica
}

\author{
Paola Vieitas VERGUEIRO
}

São Paulo, SP, Brasil.

\section{Resumo}

estudo de caso apresentado demonstra uma maneira de utilizar recursos expressivos em psicoterapia e a análise simbólica desse processo. Ele se dedica à trajetória de um paciente que, ao ingressar em psicoterapia, sofre de ansiedade intensa e não vê perspectivas na vida. A leitura psicodinâmica identifica a ação acentuada de complexos e a falta de contato com o mundo interno. Ao longo do processo o paciente acessa seu inconsciente mediante o contato com os sonhos, sua expressividade plástica e diálogo com a psicoterapeuta. Muitas conquistas são realizadas: os complexos materno e paterno são revisitados e transformados; a conscientização de conteúdos inconscientes por meio da compreensão simbólica oferece ao paciente um caminho para sua energia psíquica, o que resulta em uma nova vitalidade; a perspectiva simbólica passa a fazer parte da sua vida, antes aprisionada a uma visão literal, concreta. Uma vez em posse desses recursos, sua personalidade se fortalece e seu herói se manifesta, voltando a lhe oferecer protagonismo e perspectivas criativas na vida. Este trabalho busca, assim, aproximar estudo e prática em psicologia analítica: a pesquisa acadêmica, o atendimento clínico, a fundamentação teórica e o uso da expressividade

Conflito de interesses: A autora declara não haver nenhum interesse profissional ou pessoal que possa gerar conflito de interesses em relação a este manuscrito. plástica, sem a pretensão de esgotar as possibilidades de leitura e compreensão do caso ou das áreas de conhecimento abordadas.

\section{Descritores}

arte-terapia, psicoterapia analítica, símbolos.

Recebido: 17 maio 2017; 1 1a revisão: 08 jun 2017; Aprovado: 12 jul 2017; Aprovado para publicação: 24 jul 2017. 


\title{
The expressive psyche: The study of a psychotherapeutic process combined with plastic production
}

\begin{abstract}
The present case study demonstrates a way of using expressive resources in psychotherapy and the symbolic analysis of this process. It is dedicated to the trajectory of a patient who, when starting psychotherapy, suffers from intense anxiety and was unable to visualize a future for his life. The psychodynamic reading identifies the accentuated action of complexes and lack of contact with the inner world. Throughout the process the patient accesses his unconscious through his dreams, his expressiveness and the dialogue with the psychotherapist. Many achievements are made during the process: the maternal and paternal complexes are revisited and transformed; the awareness of unconscious contents through symbolic understanding creates a path for his psychic energy, which results in a new vitality; the symbolic perspective becomes part of his life, previously imprisoned in a literal, concrete vision. Once in possession of these resources, his personality strengthens and his hero manifests himself, returning to offer him protagonism and creative perspectives in life. This work seeks, therefore, to bring together analytical psychology study and practice: academic research, clinical care, theoretical foundation and the use of plastic expressiveness, without the intention of exhausting the possibilities of reading and understanding the case or the areas of knowledge addressed.
\end{abstract}

\section{Descriptors}

art therapy, analytical psychotherapy, symbol. 


\title{
La psique expresivo: el estudio de un proceso psicoterapéutico combinado con la producción plástica
}

\begin{abstract}
Resumen
El estudio de caso presentado demuestra una manera de utilizar los recursos expresivos en la psicoterapia y realiza el análisis simbólico de este proceso. Se dedica a la historia de un paciente que, al entrar en la psicoterapia, sufre de ansiedad intensa y no ve perspectivas en la vida. La lectura psicodinámica identifica la intensa acción de complejos y la falta de contacto con el mundo interior. Durante todo el proceso el paciente accede a su inconsciente mediante sus propios sueños, su expresión plástica y el diálogo con el psicoterapeuta. Muchos logros son obtenidos durante el proceso: los complejos maternos y paternos son revisados y procesados; el conocimiento de los contenidos inconscientes mediante la comprensión simbólica proporciona al paciente un camino para su energía psíquica, lo que se transforma en una nueva vitalidad; la perspectiva simbólica se convierte en parte de su vida, antes encarcelada en una visión literal, concreta. Una vez en posesión de estos recursos, su personalidad se fortalece y su héroe se manifiesta, volviendo a ofrecerle liderazgo y perspectivas creativas en la vida. Este trabajo busca así mismo, establecer relaciones entre el estudio y la práctica en psicología analítica: la investigación académica, la atención clínica, la base teórica y el uso de la expresión plástica, sin pretensión de agotar las posibilidades de lectura y comprensión por las áreas de conocimiento abordadas.
\end{abstract}

\section{Descriptores}

arte-terapia, psicoterapia analítica, símbolo. 


\section{Introdução}

Este estudo trata de um atendimento em psicoterapia junguiana, durante dois anos e três meses, que se inicia quando o paciente está com 49 anos. Ele é apresentado com o nome fictício de Érico. O paciente, um artista plástico, permeia o processo psicoterápico com pinturas e desenhos que realiza nas sessões e fora delas. Ao contemplar sua linguagem preferencial, a psicoterapia acolhe a expressividade espontânea do paciente. Essa é uma das metas deste estudo: demonstrar como o atendimento do paciente dentro de suas particularidades recebe, da teoria e da prática junguianas, apoio amplo o suficiente para responder às demandas de diferentes tipos psicológicos e suas linguagens.

O relato representa um recorte da totalidade de informações inerentes ao caso. Não pretende, portanto, esgotar a extensa simbologia que apresenta, nem tampouco tomar o processo psicoterápico como fórmula única e definitiva de resposta às necessidades do paciente. Pretende, sim, colocar em relevo a riqueza de suas imagens e, a partir delas, apresentar fundamentos para o uso de recursos expressivos na psicoterapia de orientação junguiana.

\section{Alguns conceitos da psicologia analítica}

A dinâmica da psique predispõe, para Jung (1975), o contato da consciência com conteúdos inconscientes. Quando conteúdos desconhecidos da psique emergem na consciência há a transformação da psique como um todo. Por outro lado, o próprio inconsciente se transforma ao se expressar.

○ contato com as emoções via expressão direta ou indireta (projeções e símbolo) favorece a conscientização de conteúdos inconscientes. Jung (1990a) emprega afeto como sinônimo de emoção e afirma: "A base essencial de nossa personalidade é a afetividade. Pensar e agir são, por assim dizer, meros sintomas da afetividade" (Jung, p. 31; OC III: 78).

afeto tem suas raízes na dimensão corporal, fisiológica, e se relaciona com as sensações. Em seu aspecto psíquico, está ligado ao sentimento, embora dele se diferencie pelo fato de o sentimento ser uma das funções da consciência. $\bigcirc$ afeto discrimina o sentimento como um processo que relaciona o eu a um certo conteúdo e concede a este um valor determinado, considerando-o agradável ou não.

Produz-se também como uma disposição que pode prescindir do conteúdo consciente momentâneo ou das percepções, podendo estar ligado a uma memória. Sentir é um processo subjetivo e tem uma disposição julgadora. Apesar da distinção entre emoção e sentimento, a ligação entre ambos é intrínseca. $O$ sentimento pode ser movido pela vontade, ao passo que a emoção, em geral, não. As emoções não são manejáveis como as ideias ou 
os pensamentos, pois são idênticas a certas condições físicas e, assim, profundamente enraizadas na matéria pesada do corpo (Jung, 1989).

Hillman (1992) enfatiza que a transformação da emoção é sinalizada pelo símbolo, que contém uma organização, uma intensidade específica de energia e indica a direção da transformação. A emoção carrega consigo, portanto, a capacidade de transformação no sentido da restauração do equilíbrio psíquico. Como forma de condensação ou resultado, afirma Hillman (1992): "Emoção é a transformação da energia do seu ambiente convencional mediante assimilação pela psique total, iniciada por um símbolo" (p. 287). O símbolo, por sua vez, é constantemente construído e transformado pela psique. Funciona como instância mediadora entre a consciência e o inconsciente, alterando, em consequência, os estados emocionais originais. A leitura de aspectos emocionais por meio da comunicação simbólica oferece, do ponto de vista da psicologia analítica, informações sobre as particularidades psíquicas de cada indivíduo, sobre a relação entre consciente e inconsciente, pondo em evidência os movimentos necessários ao desenvolvimento.

O conceito de projeção tem grande importância para a compreensão da expressividade. A demonstração do valor do desenho como instrumento de investigação do desenvolvimento geral, de psicopatologias e de aspectos da personalidade foi feita por pesquisadores, que compreenderam o valor desse instrumento com base no conceito de projeção (Kolk, 1984; Trinca, 1976; Hammer, 1989). A maior parte das pesquisas sobre a projeção nos processos expressivos tem fundamento psicanalítico e entende que a projeção está ligada, basicamente, a mecanismos de defesa. Não obstante essa tendência, o próprio Freud (1987), em "Totem e tabu", abriu a possibilidade de serem projetados conteúdos que não fossem defensivos: "A projeção não é especialmente criada para fins de defesa, mas também surge quando não existem conflitos" (p. 857). Sua origem e abrangência são, portanto, mais amplas do que aquelas reconhecidas em processos defensivos. $\bigcirc$ efeito da projeção dos processos psíquicos primários sobre o mundo externo é o animismo, o pensamento mágico e a onipotência próprios dos povos nativos, da criança e do neurótico. A criação artística, segundo Freud, é também uma projeção do artista na própria obra.

De acordo com Telles (2000), o conceito de projeção implica referências muito profundas e complexas que não poderiam ser ignoradas na escolha do termo. Envolve, em resumo, praticamente todos os problemas que a ciência psicológica busca explicar:

Dentro do próprio assinalamento de Freud [...] sobre a projeção "normal" está implícita a estrutura geral do indivíduo: antes de mais nada, sua forma sensório-perceptiva de informar a realidade 
à qual ele compartilha com congêneres de sua espécie [...]; toda problemática do aprendizado [...]; todo estudo da memória e da própria percepção (estudos modernos sobre senso-percepção, por exemplo), enfim toda relação entre "consciente" e "inconsciente" está em jogo [...]. (p. 67)

Assim, na concepção psicanalítica, o conceito de projeção está ligado de maneira intrínseca à estrutura da psique humana e responde a sua concepção de psique. Jung (2009) entende que projeção:

Significa transferir para um objeto um processo subjetivo. [...] $\mathrm{A}$ projeção é, portanto, um processo de dissimilação, ao retirar-se ao sujeito um conteúdo subjetivo e incorporado de certa forma ao objeto. Pela projeção o sujeito se livra de conteúdos penosos ou incompatíveis, mas também de valores positivos que, por qualquer motivo, como, por exemplo, a autosubestima, são inacessíveis a ele. (p. 436; OC VI: 881)

Jung (2009) ressalta ainda que o processo de projeção acontece quando há necessidade de desfazer o estado de identidade entre sujeito e objeto: "Baseia-se a projeção na identidade arcaica entre sujeito e objeto, mas só se pode denominá-la projeção quando aparece a necessidade de dissolver a identidade entre sujeito e objeto" [destaque no original] (p. 436; OC VI: 881).

Com base nesses pressupostos, acredita-se que o contato com projeções realizadas no processo expressivo pode acrescentar à consciência do sujeito uma série de informações, favorecendo, assim, seu autoconhecimento e desenvolvimento.

A compreensão do símbolo como aquele que une, faz a ponte entre aspectos do psiquismo, é tratada por diversos autores na psicologia analítica. Segundo Whitmont (2002), a busca pela experiência simbólica tem urgência e significado para o nosso tempo e encontra uma expressão útil e completa na psicologia analítica. As dimensões entre as quais estabelece diálogo são diversas: o abstrato e o material; o individual e o coletivo; o passado e o futuro; o divino e o terreno; o consciente e o inconsciente.

Diante de sua complexidade, em sua composição participam dados de natureza racional e irracional, provenientes das diferentes funções da consciência (pensamento, sentimento, sensação e intuição). Jung (2009) afirma que:

O símbolo é sempre um produto de natureza altamente complexa, pois se compõe de dados de todas as funções psíquicas. Portanto, não é de natureza racional nem irracional. Possui um lado que fala à razão e outro inacessível à razão, pois não se constitui apenas de dados racionais, mas também de dados irracionais fornecidos pela simples percepção interna e externa. A carga de pressentimento e de significado contida no símbolo afeta tanto o pensamento quanto 
- sentimento, e a plasticidade que lhe é peculiar, quando apresentada de modo perceptível aos sentidos, mexe com a sensação e a intuição. (p. 912; OC VI: 912)

Na teoria junguiana, a forma pela qual acontece a transformação psíquica relaciona-se com a abordagem semiótica e simbólica. A semiótica refere-se ao ponto de vista causal, e a simbólica, ao final. No trecho que segue, Jung (1990b) afirma a importância de ambos:

Não pode haver evolução apenas com intenção e vontade. É preciso que haja também o símbolo atrativo, cuja quantidade de valor supere o da causa. Também não pode haver formação do símbolo sem que a alma se detenha, por um tempo bastante prolongado, nos fatos elementares, isto é: até que a necessidade interior ou exterior do processo vital produza uma transformação na energia. (p. 23; OC VIII/1: 47)

$\bigcirc$ interesse fundamental de Jung em relação aos símbolos reside na capacidade destes de transformar e de redirecionar energia instintiva. A criatividade, ou instinto criativo como Jung o denomina, é uma das formas de canalização da energia instintiva. Jung considera que a evolução depende da integração do símbolo à personalidade, e esta, por sua vez, decorre tanto da intenção consciente (do ego) como da transformação natural que opera na psique.

A imagem veicula o símbolo: é a maneira pela qual ele se expressa. A compreensão de quando uma imagem é simbólica é imensamente importante para a teoria junguiana. Considera-se a presença de um símbolo vivo quando a imagem constitui a melhor expressão de algo que tem significado. O símbolo vivo é prenhe de sentido e abriga aspectos desconhecidos. $O$ fato de uma imagem ter valor simbólico depende principalmente da atitude do observador. Dessa maneira, para que haja transformação da energia psíquica, a atitude do sujeito para com o símbolo é fundamental.

Fordham (1957) afirma que os conceitos de imagem e símbolo não devem ser confundidos e o conteúdo de qualquer imagem em particular - seja produto de sonho, seja produto da imaginação - pode trazer questões complexas que tendem a se refletir no diversificado uso da palavra símbolo. No caso da visão de um objeto externo, os neurônios estimulados no cérebro formam um padrão no córtex diferente do modelo do objeto em observação. Nesse sentido, a concepção de imagem original como uma reprodução fotográfica não se sustenta; trata-se, aparentemente, do dado que se tem para relacionar a imagem mental ao objeto externo. Essa imagem é chamada simbólica por neurofisiologistas porque representa, de maneira próxima o suficiente, o objeto externo, para ser estabelecida sua existência mental por inferência. 
É evidente que a psicologia analítica, ao tratar a imagem, não se refere à reprodução mental do objeto exterior, mas à imagem interior, produto da fantasia. Esta imagem se relaciona somente de maneira indireta ao objeto exterior. A teoria junguiana considera a imagem interior como uma composição de materiais diversos, complexa, mas dotada de sentido próprio e unidade. É também expressão de conteúdos inconscientes, aqueles que têm utilidade no momento. Dessa maneira, a imagem expressa a situação do momento, tanto consciente como inconsciente, baseando-se em suas relações mútuas. Para Jung, embora não se atribua habitualmente à imagem um valor de realidade, em certas circunstâncias, ela pode representar uma realidade íntima que pode superar o significado psicológico da realidade exterior. Esta realidade íntima é uma unidade que possui sentido próprio e uma utilidade ao sujeito em questão. É produto da relação entre a consciência e o inconsciente.

Segundo Furth (2004), Jung enxergava o valor das vias expressivas para a produção de símbolos, no entanto, não desenvolveu nenhum método para a interpretação de tais produções.

$\mathrm{Na}$ teoria junguiana (1986a), o processo que coloca em relação os contrastes, os opostos psíquicos, é nomeado de função transcendente, necessária à formação de símbolos que expressam polaridades:

Por "função transcendente" não se deve entender algo de misterioso e por assim dizer suprassensível ou metafísico, mas uma função que, por sua natureza, pode-se comparar com uma função matemática de igual denominação, e é uma função de números reais e imaginários. A função psicológica e "transcendente" resulta da união dos conteúdos conscientes e inconscientes. (p. 96; OC $\mathrm{VIII/2:} \mathrm{131)}$

Trata-se de um processo natural que pode ser estimulado externamente. A manifestação produzida pela tensão dos contrários pode assumir forma visível pelas expressões plástica, escrita ou dramatizada. Esse produto de caráter simbólico é produzido pela tensão dos contrários e também os expressa.

O símbolo pode ser visto como terceiro fator na relação mente/corpo, segundo Ramos (2006). De acordo com a autora, a mente, por sua capacidade de simbolizar, pode ser considerada uma produtora de códigos, processadora e transmissora de informações do organismo tanto para a psique como para o soma. A informação recebida e processada no nível semântico pode ser traduzida em informação a ser recebida e processada no nível somático e vice-versa. $\bigcirc$ conceito de Jung de símbolo como transformador de energia pode ser compreendido como um transformador de informações de um sistema (imunológico, por exemplo) para outro (consciência, por exemplo). 
A forma de trabalhar nessa relação varia de caso para caso. Segundo a autora, a transição de sintomas orgânicos ou emocionais para o plano consciente pode ser feita mediante diferentes recursos. Jung descreve a imaginação ativa e métodos como drama, produções visuais (pintura, desenho, modelagem) ou a dança como produtores, em alguns casos, de efeitos terapêuticos notáveis. Toda doença tem expressão na psique e no corpo simultaneamente, segundo Jung (1986a):

Como a psique e a matéria estão encerradas em um só e mesmo mundo, e, além disso, se acham permanentemente em contato entre si, e em última análise, se assentam em fatores transcendentes e irrepresentáveis, há, não só a possibilidade, mas até mesmo a probabilidade de que matéria e psique sejam aspectos diferentes de uma e mesma coisa. (p. 152; OC VIII/2: 418)

\section{Breve histórico do uso de recursos expressivos na área da saúde}

Podemos dizer que cada gesto, expressão ou resposta de um indivíduo traduz, de alguma maneira, a personalidade de quem o produz. $\mathrm{Na}$ produção plástica, as atividades psicomotoras e os conteúdos gravados no papel expressam tendências do indivíduo.

O estudo da expressividade artística e a aplicação de diferentes linguagens expressivas na área da saúde aconteceram a partir do século XIX. Em 1876, Max Simon publicou pesquisas sobre manifestações artísticas de doentes mentais e fez uma classificação das patologias a partir destas. Em 1888, Cesare Lombroso fez análises de desenhos de doentes mentais buscando identificar psicopatologias. Jean-Martin Charcot e Charles Richet também estudaram e se interessaram pela arte dos doentes mentais (Carvalho \& Andrade, 1995).

No Brasil, dois nomes aliaram as expressões artísticas ao tratamento: Osório César, em São Paulo, e Nise da Silveira, no Rio de Janeiro. Como Jung, esta última usou o teatro, a dança, a escrita e a pintura como meios de produção de imagens espontâneas.

Nos Estados Unidos, a partir dos anos 1940, a sistematização da arteterapia por Margareth Naumburg (1955) trouxe impulso ao uso da arte no campo da saúde. Afirma Naumburg (1955): "A intelectualização e o verbalismo exagerado da nossa cultura foram impostos sobre os níveis mais profundos e mais primitivos da nossa modalidade inconsciente de expressão por meio de imagens" (p. 435). Segundo Carvalho e Andrade (1995), outra vertente foi criada por Edith Kramer, centrada no valor terapêutico do processo criativo e do fazer artístico em si; e uma terceira vertente desenvolveu-se a partir do trabalho de Janie Rhyne, que afirma que o valor terapêutico da atividade artística está tanto no processo de criação quanto nas possíveis reflexões e elaborações posteriores sobre os trabalhos realizados. 
Em função das diversas maneiras de utilizar os recursos expressivos aliados à terapia, vê-se, hoje, no campo da arteterapia, a preocupação com a utilização de diferentes nomenclaturas em relação aos variados enfoques.

O crescimento dessa área de natureza interdisciplinar permitiu que a arteterapia passasse a ser aplicada em consultório e instituições de diferentes tipos, atendendo a diversas faixas etárias e demandas em saúde (Ciornai, 2004). Ao lado da sua expansão, surgiram discussões buscando esclarecer seus contornos teóricos e metodológicos. Vasconcelos e Giglio (2006) afirmam duas grandes tendências no campo da arteterapia: "art as therapy" e "art psychotherapy", e comentam: "É imprescindível considerar que as duas tendências citadas compõem o campo da arteterapia, não havendo ainda uma distinção conceitual clara utilizada no Brasil." (p. 43).

Segundo Samuels, Shorter e Plaut (1988), Jung introduziu o termo imaginação ativa em 1935 para descrever o processo de sonhar com olhos abertos:

De saída, o indivíduo concentra-se em um ponto específico, uma disposição, quadro ou eventos específicos; em seguida, permite que uma cadeia de fantasias associadas se desenvolva e gradativamente assuma um caráter dramático. Depois as imagens ganham vida própria e desenvolvem-se de acordo com uma lógica própria. A dúvida consciente deve ser superada e consequentemente que haja permissão para que qualquer coisa incida na consciência. (p. 99)

procedimento permite que conteúdos anteriormente isolados tornem-se mais ou menos claros e articulados. É possível lidar de diferentes maneiras com o conteúdo que se manifesta (Samuels et al., 1988):

processo da imaginação ativa pode, ele próprio, ter um efeito positivo e vitalizante, porém o conteúdo (como de um sonho) também pode ser pintado [...]. Os pacientes podem ser motivados a anotar suas fantasias a fim de fixar a sequência em que ocorreram e tais registros podem, subsequentemente, ser levados à ANÁLISE para a INTERPRETAÇÃO [destaques do original]. (p. 100)

Na década de 1920, Jung começou a usar a linguagem expressiva artística como parte do tratamento. Ele permitia que, em certos casos, pacientes expressassem plasticamente seus sonhos e percebia nos símbolos produzidos possibilidades de cura. Na sua concepção, o reino do inconsciente, tanto na sua dimensão coletiva como na pessoal, pode ser representado artisticamente por meio das imagens e de símbolos. Esses símbolos podem aparecer em diferentes linguagens, na dança, na música, na expressão plástica. Para Jung, tais técnicas permitem que o paciente seja ativo diante de sua própria psique; ele age em direção a sua compreensão, ao materializar suas fantasias e sonhos. Depois, ao defrontar-se com as características e detalhes de sua produção, aproxima-se da sua própria vida 
e muda o enfoque diante dela. É como se deslocasse o seu centro de gravidade ao identificar forças que reconhece como importantes, das quais não tinha consciência anteriormente.

O tratamento da psique, na abordagem junguiana, leva em conta 0 movimento natural para o seu desenvolvimento, o que pode ser favorecido mediante a disposição da consciência para o contato com os elementos que emergem do inconsciente. Jung afirma que o inconsciente complementa ou compensa o consciente, na direção do equilíbrio. O psicoterapeuta é capaz de acompanhar e favorecer o movimento psíquico do paciente. Processos expressivos podem propiciar essa comunicação.

\section{Expressividade e personalidade: fundamentos da interpretação das imagens}

A ideia de que cada ato, expressão ou resposta de um indivíduo apresenta, de certa maneira, a sua personalidade é popular. Seus princípios demonstram-se na ação de diferentes pesquisadores, que se dedicam ao estudo sistemático de obras de arte ou de produções plásticas em contextos diversos, buscando revelar aspectos da personalidade de quem os produziu. As produções humanas são um material bruto a partir do qual os psicólogos podem forjar instrumentos clínicos.

Bruchon (1972) considera que "os movimentos expressivos podem oferecer ao estudo da personalidade humana uma informação complementar preciosa e original". As condutas psicomotoras dizem respeito a traços psicodinâmicos, projetivos, de temperamento, aspectos expressivos e adaptativos.

Os estudos sobre a personalidade via expressão plástica que vêm demonstrando resultados sistemáticos são principalmente voltados para a investigação do desenho cromático ou acromático. Ao estudar desenhos realizados pelas mesmas pessoas, em intervalos de tempo, Machover (1949) observou que os seus aspectos estruturais e formais estão menos sujeitos à variabilidade do que seus aspectos de conteúdo. Se um indivíduo faz sua figura grande ou pequena, onde a coloca na página, se trabalha com linhas contínuas largas ou curtas, com linhas dentadas, se a figura tem uma pose agressiva, se está rígida ou fluida, como são as proporções essenciais do corpo, se há disposições simétricas, se existe uma tendência a deixar partes incompletas, erros, sombreamentos, todos estes são fatores que se referem à estrutura da personalidade. Desenhos de pacientes podem manter essas características formais notavelmente parecidas ao longo de anos. Esse é um indício da profundidade e da estabilidade dos parâmetros que o aspecto expressivo oferece sobre a personalidade do sujeito estudado.

Kolk (1984) destaca a capacidade do desenho de expressão para o desenvolvimento geral e o da psicopatologia e como meio de contato para a investigação e o tratamento psicoterápico. Para a interpretação do desenho, parte-se de uma visão fenomenológica, em que se leva em conta o 
significado funcional das partes envolvidas e chega-se a uma análise simbólica. Um traço isolado nada significa: cada detalhe deve ser visto em sua relação com o todo.

Trinca (1976) explora as técnicas de apercepção temática e o desenho livre. Descreve as técnicas gráficas que incluem histórias e o instrumento do desenho-história como auxiliar na investigação da personalidade. A sequência é considerada pelo autor como útil ao processo expressivo. A profundidade de compreensão proporcionada pela continuidade das produções já havia sido investigada por Caligor (1952).

Hammer (1989) propõe uma estrutura geral para a leitura de desenhos projetivos com a observação dos seguintes aspectos: sequência, tamanho, pressão, traços, detalhes, simetria, localização e movimento. Ele afirma que desenhos de pacientes tendem a demonstrar constância em seus aspectos estruturais ao longo dos anos.

Furth (2004) propõe uma técnica de leitura de imagens, baseada na teoria dos complexos de Jung, que ele chama de "ponto focal", que inicia com a observação da primeira impressão buscando identificar os aspectos centrais dos desenhos. Posteriormente, deve-se perguntar sobre os materiais, tamanho do papel e sua relação com o desenho: cor, forma, direção, movimento, posicionamento, número de objetos apresentados e omitidos. $\mathrm{E}$, a seguir, sintetiza-se o que se descobriu a partir dos componentes individuais. Essas informações são reunidas como um todo, levantando hipóteses sobre a direção para a qual elas apontam. Uma vez que todos os complexos estejam interligados, pode-se fazer contato com eles a partir de qualquer conteúdo, pois um conteúdo leva a outro (da mesma maneira que um complexo leva a outro). O significado apriorístico de determinados aspectos expressivos tem valor relativo para Furth (2004). Deve-se conhecêlos, mas não se apegar a eles. A relação entre os diferentes elementos que compõem a particularidade de cada produção pode oferecer um sentido novo a um determinado significado previamente reconhecido.

Bach (1990) estudou desenhos espontâneos de crianças com doenças graves. Para a interpretação das imagens, propôs parâmetros a fim de compreender o uso da cor, da orientação espacial, de unidades de tempo e de alguns temas específicos, compreendidos como arquetípicos.

Abt (2005) considera que "Este mágico efeito da criação de imagens é um primeiro passo na transformação de emoções" (p. 33). Para ele, todos nós nascemos com a habilidade de ler imagens. Todas as crianças pequenas e suas mães compreendem umas às outras com a ajuda da leitura corporal, que é uma linguagem pictórica. As escolhas feitas para compor uma produção plástica têm sempre um sentido do qual podemos nos aproximar por meio da compreensão simbólica. $\bigcirc$ estudo dos símbolos na abordagem junguiana pressupõe a compreensão de que a psique apresenta diferentes dimensões. Em função disto as imagens são observadas como produto de uma estrutura arquetípica na qual coexistem conteúdos dos inconscientes coletivo e pessoal e da consciência. A estrutura arquetípica que uma imagem 
expressa é passível de leitura. Os motivos típicos oferecem ao leitor de imagens experimentado orientações sobre seu sentido, mas não esgotam a questão. Sua dimensão pessoal, que inclui a consciência e o inconsciente pessoal, depende da interlocução com aquele que produziu a imagem para que possa ser esclarecida. A compreensão da imagem depende do entendimento da relação entre todas as dimensões de consciência expressas nesta.

\section{Estudo de caso como método investigativo}

Conforme afirma Chizzotti (2003), o estudo de caso é uma

[...] caracterização abrangente para designar uma quantidade de pesquisas que coletam e registram dados de um caso particular ou de vários a fim de organizar um relatório ordenado e crítico de uma experiência, ou avaliá-la analiticamente, objetivando tomar decisões a seu respeito ou propor uma ação transformadora. (p. 102)

Esse método se baseia no pressuposto de que o caso é uma unidade significativa do todo e, portanto, é suficiente para fundamentar um julgamento fidedigno e para propor uma intervenção. Não foram utilizados instrumentos padronizados de avaliação para monitorar o estado do paciente e sua evolução.

Neste estudo, escolheu-se avaliar, descrever e discutir o caso clinicamente, de acordo com a referência teórica da psicologia analítica de C. G. Jung. A análise foi feita mediante uma abordagem longitudinal focada nas imagens trabalhadas nas sessões e ofereceu a noção de todo, tratando do caso do começo ao fim.

Ao considerarmos a abordagem clínica, diversas são as comunicações do paciente suscetíveis à interpretação. Este estudo teve como foco a expressividade plástica porque $\bigcirc$ paciente escolheu expressar-se prioritariamente pela plástica.

Nesse sentido, o trabalho foi favorecido ao acatar sua comunicação de preferência. Somou-se a isso o interesse em demonstrar a riqueza da psicologia analítica, permeável a diferentes linguagens e, particularmente, à quantidade e à qualidade das informações advindas da interpretação de imagens.

Sobre o uso da expressividade no atendimento

Ao longo deste estudo, a psicoterapeuta será nomeada por " $\mathrm{P}$ ". Em sua primeira sessão, $P$. recebe as queixas do paciente e apresenta sua forma de trabalho. Diz a Érico para que ele fique à vontade para se expressar plasticamente. Ele passa então, naturalmente, a dizer em algumas sessões: "hoje quero pintar!" e faz isso com rapidez e alegria. Uma vez finalizadas as produções, P. pede para que ele fale a respeito. Pergunta se as obras têm 
nomes, o que ele vê nelas e o que elas the permitem lembrar ou associar. Habitualmente, o paciente fala pouco sobre elas.

Após a fala de Érico, como forma de estímulo e investigação, P. descreve os aspectos plásticos da produção. Sugere, com isso, a ampliação do contato de Érico com sua obra. No processo de Érico, essa aproximação costuma favorecer a emergência de sentimentos e associações, que são considerados no processo de leitura de cada produção. Outros fatores ligados ao atendimento clínico entram na cena da leitura da expressão: o histórico de Érico e a leitura do caso, as amplificações por ele sugeridas e a própria disposição subjetiva de P. para compreendê-lo.

Sobre o método de manejo e de análise de imagens

A investigação do processo expressivo de Érico tem como ponto de partida a sua tendência expressiva. Érico prefere, muitas vezes, pintar a falar sobre o que está vivendo. A expressão plástica é a linguagem principal de Érico. Nesse sentido, a leitura do caso prioriza as produções plásticas e busca vinculá-las às verbalizações. Na abordagem às imagens plásticas, procura-se evidenciar apenas os conteúdos centrais de cada comunicação, enfatizando a sequência de produções, uma vez que a leitura detalhada de imagens é um trabalho complexo e demorado. Diversos são os caminhos para nos aproximarmos de uma imagem. Adota-se aqui o método de Furth (2004), por se tratar da maneira mais resumida. Além do levantamento do ponto focal em cada imagem, procura-se relacionar os principais temas evidenciados ao longo de todo o processo imagético, buscando compreender, ao final, o processo como um todo. Para tal, usa-se como referência o estudo de uma sequência de imagens. Jung (1991), ao analisar séries de sonhos, afirma que a sequência de produções é reveladora de movimentos do inconsciente; portanto, é fundamental para que possamos compreender sua dinâmica.

As produções de Érico se apresentam de formas muito diferentes: algumas são trazidas prontas, de casa. Outras, ele faz a caminho da psicoterapia. Algumas são feitas no consultório. Muitas são trazidas e não são trabalhadas na clínica, em função do grande volume de produções. Neste estudo, buscase centrar a atenção nas obras que foram trabalhadas no consultório, pressupondo que a escolha das produções a serem trabalhadas no setting analítico é significativa.

Dados os limites para a extensão deste estudo, será elaborado um breve resumo do processo, sem a pretensão de esgotar as possibilidades de leitura e compreensão do caso. As amplificações denotam os sentidos principais que se apresentam na mente de P., a partir da qual são expostas as possibilidades de leitura e de inclusão de conteúdos inconscientes no vaso alquímico terapêutico. Paralelamente, também são utilizados relatos verbais e sonhos. Observam-se as expressões pictóricas dos sonhos como interpretações de Érico, e não como o sonho em si. Nesse sentido, a intenção é a de ter cuidado para guardar as particularidades de cada 
âmbito expressivo: o sonho, a expressão plástica do sonho, a experiência, a expressão verbal da experiência. A comunicação de cada um desses âmbitos depende da "tradução" de Érico, perpassando sua forma de ver os fatos, e não representando o fato em si.

\section{Cuidados éticos}

caso relatado neste estudo é verídico, apenas os nomes utilizados são fictícios. $\bigcirc$ paciente foi consultado acerca da realização deste trabalho, com base em seu atendimento e forneceu o "Termo de Consentimento Livre e Esclarecido" autorizando a publicação. Os cuidados éticos relativos ao atendimento respondem às determinações formais do Conselho Regional de Psicologia (2005).

\section{Descrição do início do processo psicoterápico}

Érico tem 49 anos. É moreno, tem 1,60 m de altura (baixa para um homem), olheiras permanentes. Adota um estilo esportivo para se vestir e suas roupas são bem cuidadas. É artista plástico, segundo filho de um casal de funcionários públicos. A primeira filha do casal é mulher. Érico relata que seus pais sempre brigaram e, durante alguns anos (quando ele tinha seis ou sete anos) ficaram separados. Sempre invadiram a vida dos filhos. Érico não se relaciona bem com a irmã, por considerá-la fraca, invejosa e incompetente, e conta que seus pais sempre a privilegiaram em detrimento dele.

O paciente sempre se sentiu inseguro e rejeitado, embora sua mãe tenha sido superprotetora. Considera seu pai grosseiro e machista, pois traiu sua mãe ao longo do casamento. Sua relação com ele é, desde criança, distante. Julga-se muito diferente dele: sensível, fiel e intenso nos relacionamentos. Quando criança ganhou um concurso de artes plásticas na escola, mas não teve coragem de continuar produzindo plasticamente. Sentia-se diferente de todos, e mal visto por isso. Nunca gostou de futebol, nem gostava de falar palavrão e achava que as pessoas que gostavam eram muito grosseiras.

$\mathrm{Na}$ escola, era menor fisicamente do que os colegas: franzino e baixinho. $\mathrm{Na}$ adolescência essa diferença aumentou, pois somente aos 17 anos desenvolveu um corpo maduro sexualmente; sentia-se envergonhado com isso e acha que se fechou para o mundo nessa época. Prestou o serviço militar, teve um excelente desempenho e ganhou medalha. Depois do serviço militar quis sair de Santos e veio para São Paulo, ser professor de artes. Considera que sua vida começou a desmontar há oito anos. Casou-se aos 22 anos com Carmem (nome fictício). Em suas palavras: "Há oito anos meu casamento ficou doente, foi para a UTI e depois morreu". Há um ano acordou uma separação, mas, por motivos financeiros, continua a morar com a ex-esposa na mesma casa. Seu cachorro morreu há oito anos - sofreu muito com essa perda. Deixou de ganhar dinheiro, também, há oito anos. 
Sua ex-esposa é rígida e sabe se valorizar, diferente do que pensa de si mesmo. Ela é excelente profissional. Desenvolveu uma doença de pele autoimune e tem umas manchas na pele. Ele a ajudou como pode à época, mas seu relacionamento sexual piorou muito desde então, há cerca de oito anos. Ela ficou mais esquiva, afastou-se dele. Érico afirma que ela não o ajuda quando ele precisa, mas ele a ajuda sempre. Ele dirige e ela não. Ela sempre pede carona para ele, que a transporta com prazer. Quando ele precisa de ajuda, ela é fria e indiferente. Chegou a ficar doente e ela não perguntou se ele queria um remédio. Teve que ir ao hospital sozinho. Por ganhar menos do que a ex-esposa, hoje em dia Érico depende um pouco dela financeiramente.

Tem alguns alunos e trabalhos esporádicos $\mathrm{E}$ tem procurado emprego, mas não consegue nada. É chamado para algumas entrevistas de seleção, que não resultam em contratação. Recebe algum dinheiro dos seus pais para completar o seu orçamento. Sente-se muito envergonhado com isso, acha que deveria estar oferecendo conforto aos pais com essa idade, levando-os para viajar, e não recebendo nada deles.

Tem dificuldade de acreditar na vida, pois as novidades que se apresentam parecem ou violentar sua sensibilidade ou restringir suas ambições. Sente-se sempre diminuído. As novas amizades e amores (que aparecem com frequência, pois as pessoas gostam dele) são evitados, com a desculpa de que tem que se estruturar financeiramente para depois ter experiências amorosas. Ele foge do amor. No trabalho precisa de muito reconhecimento e acolhimento, pois frequentemente se sente ofendido com comentários a seu respeito.

Nas sessões, Érico chega antes da hora e não falta, exceto em casos de extrema necessidade. Quando isso acontece avisa com antecedência que vai faltar. Agradece às sessões e elogia P. várias vezes no começo do processo. Apesar de dizer que está melhor, logo depois que começa a ser atendido por P., esta percebe que ele ainda sofre muito e que um bom caminho terá que ser percorrido para ficar bem. Érico sofre com insegurança e ansiedade e esses sintomas se mantêm por alguns meses.

\section{Tópicos principais de 2012}

Érico chega à psicoterapia realizando tratamento psiquiátrico, tomando medicamentos para depressão e ansiedade. Sente-se muito descrente da vida e permanentemente ansioso.

Fala da sua relação com a mãe, que lhe telefona várias vezes na semana. Ele sente-se culpado por evitar falar com ela. A mãe de Érico fala sem parar e o repreende por ele não the dar a devida atenção. $\bigcirc$ paciente incomodase com o fato de receber algum dinheiro dos pais, para completar seu ganho mensal. P. pergunta se ele dá atenção à mãe, pensando que deve isso a ela, pelo dinheiro que recebe. Érico responde que não, mas percebese que a pergunta o faz refletir a respeito. A temática do início é a relação 
com os pais, com a irmã e com a esposa. Não se sente bem com ninguém, não têm amigos. Quando alguém na rua "puxa papo", e faz algum comentário do tipo: "por que está tão desanimado?", afirma sentir ódio.

As primeiras imagens oníricas são de pessoas: flashes, imagens em que sente ódio de muitos rostos desconhecidos. Depois de três meses de psicoterapia sonha com uma casa antiga que queimava com seu pai dentro. Trabalha-se a imagem do pai, seu histórico com ele e a nova visão do mesmo, resultante da morte da sua antiga imagem. A nova visão do pai lança uma compreensão sobre a situação de um homem casado com uma mulher dominadora que deprecia a figura masculina. Estuda inglês na rede "Cultura Inglesa", a fim de melhorar sua chance na concorrência por uma vaga ao mestrado na Universidade de São Paulo. Esse é um dos seus planos: elaborar uma dissertação de mestrado. Mas, seguir com o curso é um problema e um desafio para Érico. Não se sente à altura dos colegas. Está sempre para desistir do curso, pois se sente humilhado por não falar inglês tão bem como eles. Conta que alguns professores reafirmaram seu potencial e favoreceram seu processo de aprendizagem. Sente-se agradecido por isso, mas não acha que seja capaz de passar de semestre. Toda vez que faz uma prova, treme, tem calafrios ou fica doente. Apresenta terríveis sentimentos de inferioridade e já desistiu muitas vezes de seguir adiante. No semestre seguinte, a escola ou algum professor o convencem a recomeçar o curso.

É sociável em sala, agita os colegas para terem amizade. Mas, quando eles o convidam para tomar uma bebida ou conversar, ele recusa, encontra alguma desculpa e não sai com eles. Vive uma vida solitária.

As produções plásticas ao longo do ano de 2012 são, basicamente, em preto e branco. Revelam afastamento do mundo interior e exterior, e ação intensa do complexo materno (Figuras 1-6).

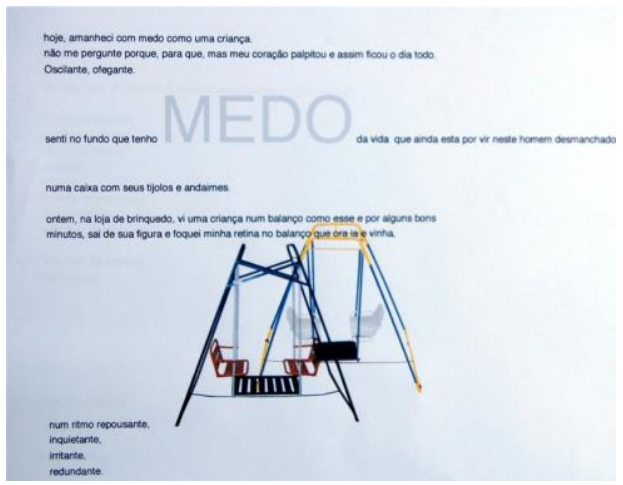

Figura 1A. 20 de novembro de 2012. Fala de Érico: "infância, medo, insegurança". Considerações de P.: aqui o tema da infância é apresentado na imagem de dois balanços vazios, brinquedos que poderiam ser divertidos com a presença de crianças. Esta imagem pode remeter à falta desse movimento em sua infância e/ou da sua criança interior. 


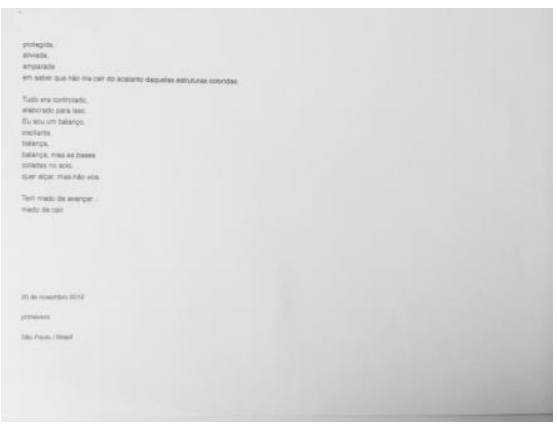

Figura 1B. 20 de novembro de 2012. Considerações de P.: relato dos sentimentos relativos à infância, insegurança e medo de voar. A presença de palavras mostra que é a dimensão racional que reconhece estes sentimentos.

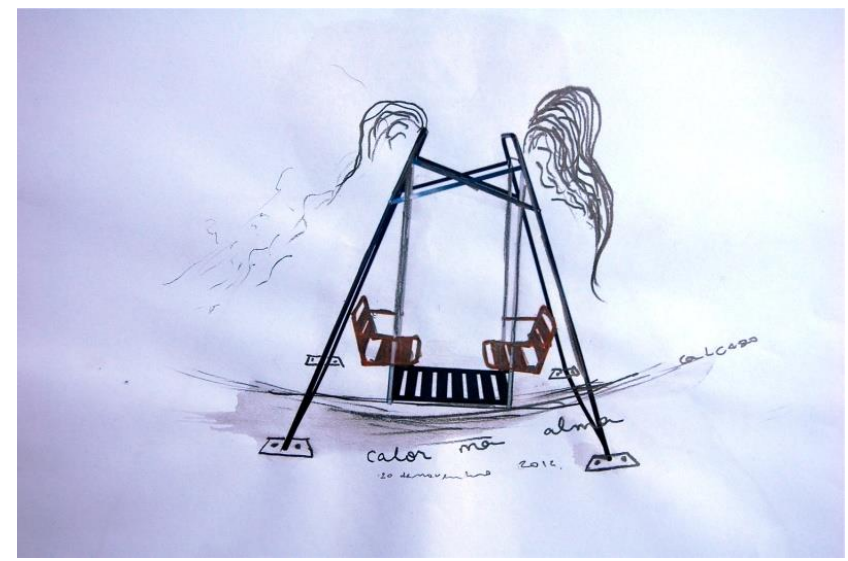

Figura 2. 20 de novembro de 2012. Fala de Érico: "não sei, parece cabelo". Considerações de P.: o balanço duplo, vazio, apresenta algo parecido com fios de cabelo na parte superior. Os fios podem ser associados ao elemento feminino, a cabelos longos, à grande mãe, à Medusa ou à Górgona. 


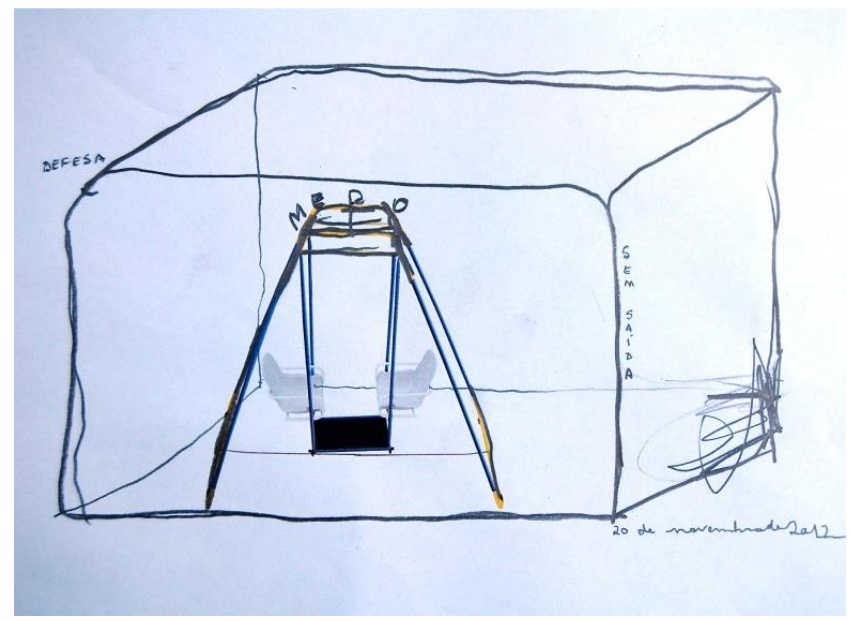

Figura 3. 20 de novembro de 2012. Fala de Érico: "é isso aí, medo de sair". Considerações de P.: o balanço duplo, agora protegido dentro de um cubo, apresenta as palavras "defesa", "medo" e "sem saída", que indicam a origem do complexo principal de Érico.

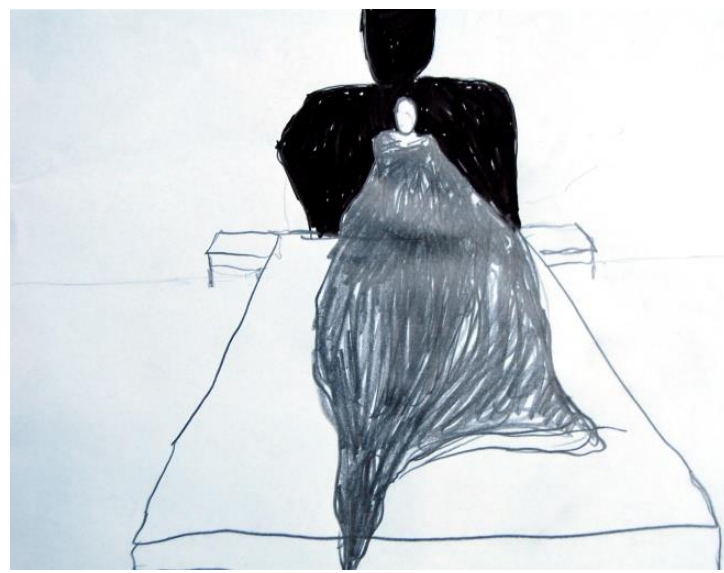

Figura 4. 27 de novembro de 2012. Fala de Érico: "eu tive um pesadelo com essa figura. É uma mulher. Um terror". Considerações de P.: a figura feminina aparece em sua face negativa, da grande mãe aterrorizante. 


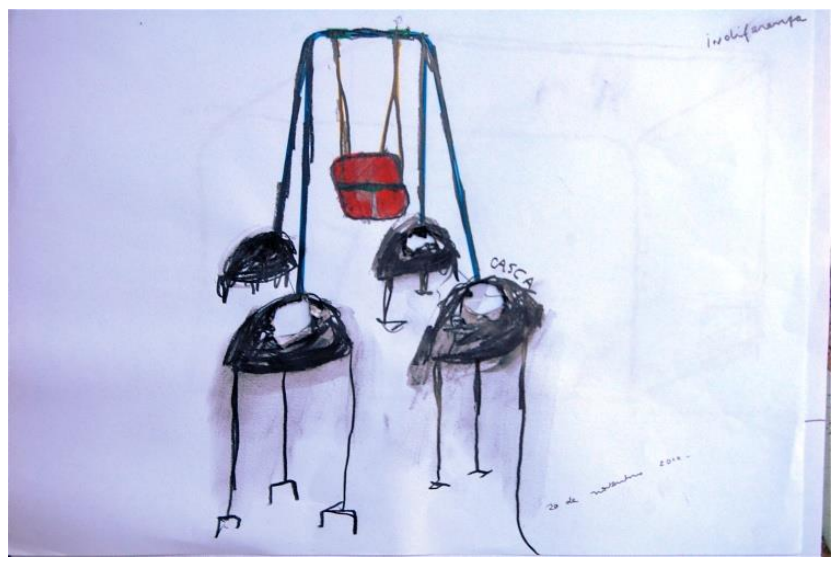

Figura 5. 27 de novembro de 2012. Fala de Érico: "não sei explicar. Esses pés têm buracos. Você está vendo que estão rasgados?" Considerações de P.: os pés do balanço parecem baratas, também uma figura sombria. A imagem revela uma vulnerabilidade - o balanço, que poderia acolher, proteger e embalar, é furado e perigoso, não oferece segurança.

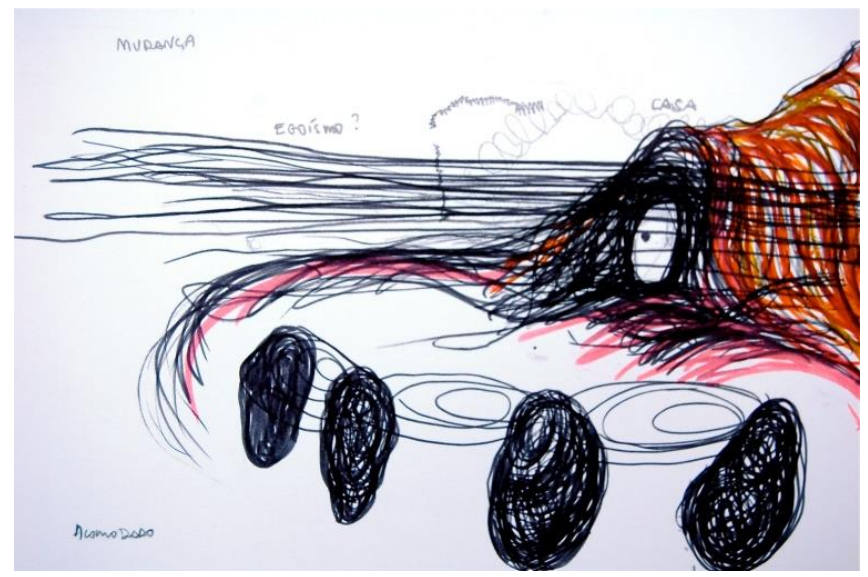

Figura 6. 27 de novembro de 2012. Fala de Érico: "as palavras acomodado, mudança e egoísmo estão na produção". Érico avalia assim sua situação e acha que está entocado na casa. Considerações de P.: Érico se mostra escondido dentro de uma toca. A toca é parte da natureza, uma raiz de árvore ou uma pedra. É parte da natureza de Érico, portanto. Não é uma construção passageira, frágil, mas muito forte e resistente.

A figura da árvore aparece repetidas vezes (Figuras 7 e 8), com grande copa e raízes, mostrando a força da personalidade de Érico; há solidão. A sugestão é que a proteção do mundo está associada a aspectos conhecidos e antigos da personalidade de Érico. 


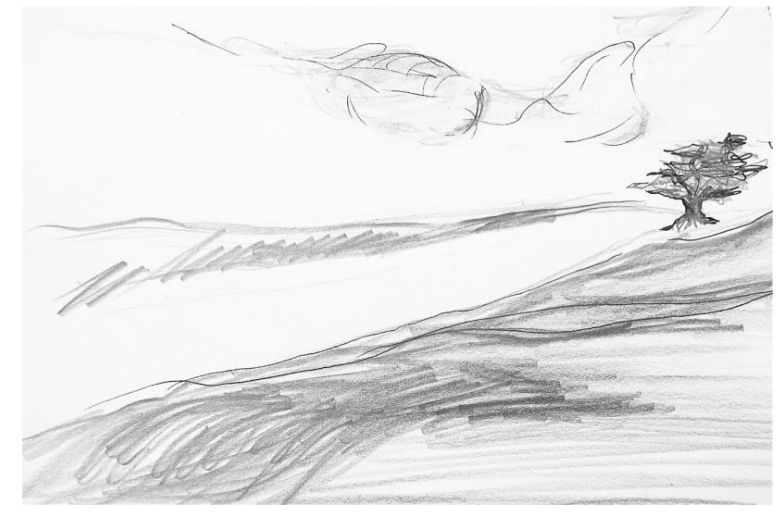

Figura 7. 28 de dezembro de 2012. Fala de Érico: "adoro desenhar árvores. Eu gosto dessa paisagem. Parece meio vazia, solitária, mas eu gosto". Considerações de P.: esta produção parece revelar outros aspectos de Érico, mais próximos da vida consciente, de sua personalidade. Existe um isolamento consciente, evidenciado pela única árvore que se apresenta no desenho. Caminhos começam a aparecer nos desenhos e uma raiz que atravessa a sua estrada. Ela é destacada, talvez ferida. De qualquer forma, o fato de estar na superfície nos permite tomar contato com as raízes de Érico.

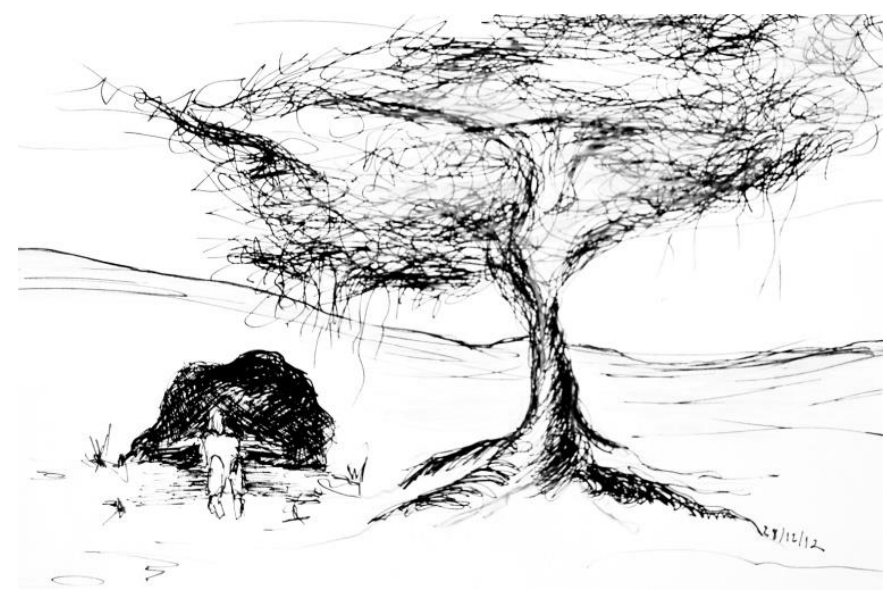

Figura 8. 28 de dezembro de 2012. Fala de Érico: "acalanto. Eu gosto dessa paisagem. Parece meio vazia, solitária, mas eu gosto". Considerações de P.: Érico descansa ao lado da árvore que é símbolo da personalidade total. Há segurança para descansar e pouca mobilidade na figura humana o que pode indicar uma paralisação na comunicação ego-self. 


\section{Tópicos principais de 2013}

A psicoterapia de Érico é marcada, no ano 2013, pela transição do estado de afastamento do mundo interior para o de uma forte relação com ele. Diversos conteúdos aparecem nas imagens em cores e movimento, revelando polaridades psíquicas, sua discriminação e a dinâmica (Figuras 927).

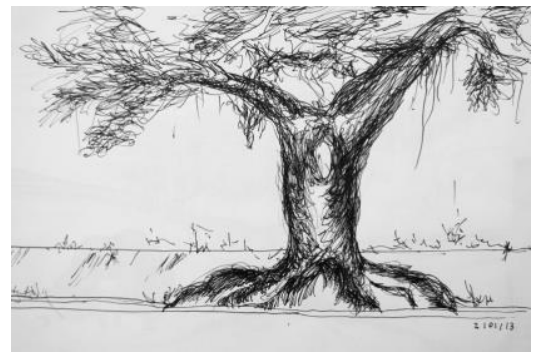

Figura 9. 02 de janeiro de 2013. Fala de Érico: "a árvore, eu gosto; acho forte". Considerações de P.: a árvore, vista bem de perto, mostra sua força. Tem raízes e galhos abundantes. $\mathrm{O}$ fato de não apresentar frutos ou flores indica afastamento da criação. O fato de não apresentar cores, indica que está expressando o aspecto estrutural da psique, vista pelo prisma da razão.

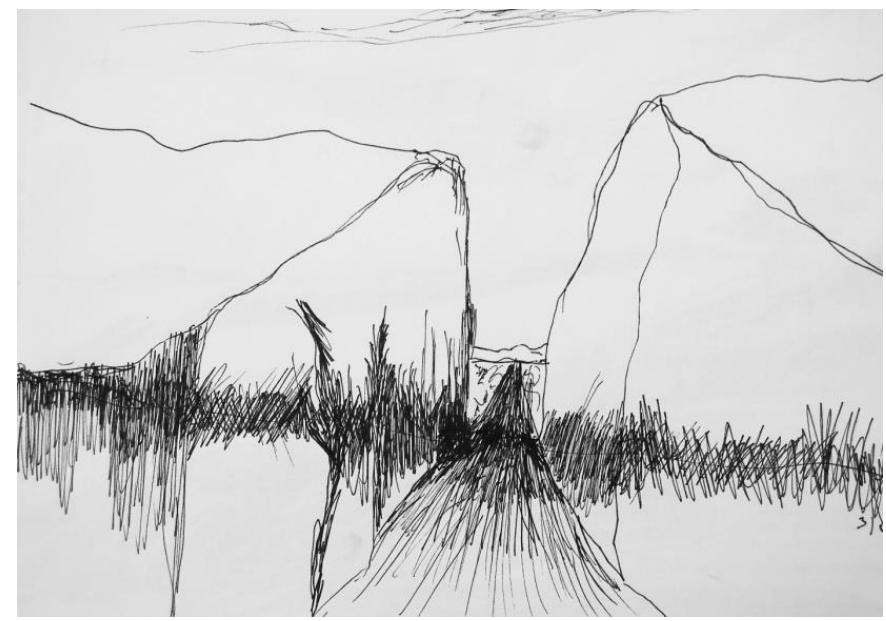

Figura 10. 03 de janeiro de 2013. Fala de Érico: "achei forte essa produção. Alguma estrada passa aqui". Considerações de P.: nesta produção, uma montanha tem uma fenda que permite a passagem de uma estrada, ao meio. A montanha é natural, material e constante. A produção remete a uma abertura realizada em aspectos estruturais da psique. 


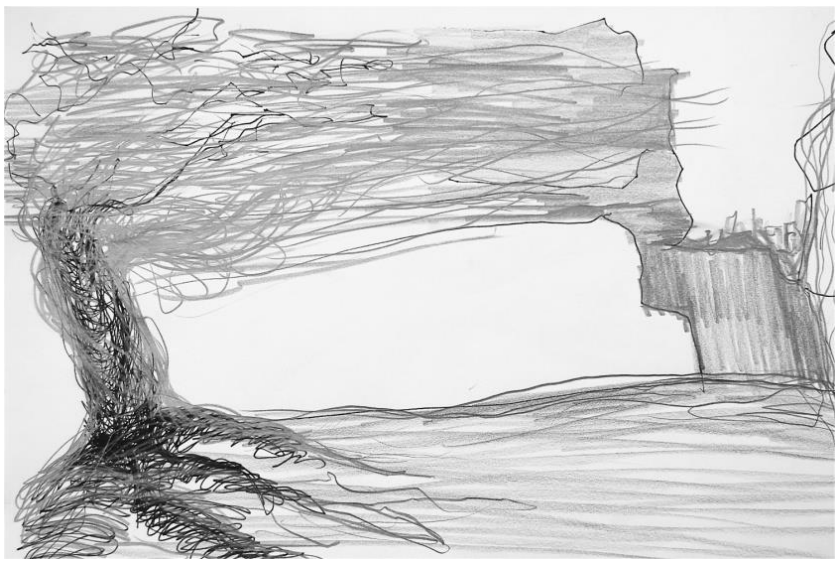

Figura 11. 15 de janeiro de 2013. Fala de Érico: “aqui é algo que não sei. Um muro, ou algo assim". Considerações de P.: a copa da árvore está unida a algo bem sólido, como um muro ou um tronco de árvore. Insinua-se uma união no plano superior.

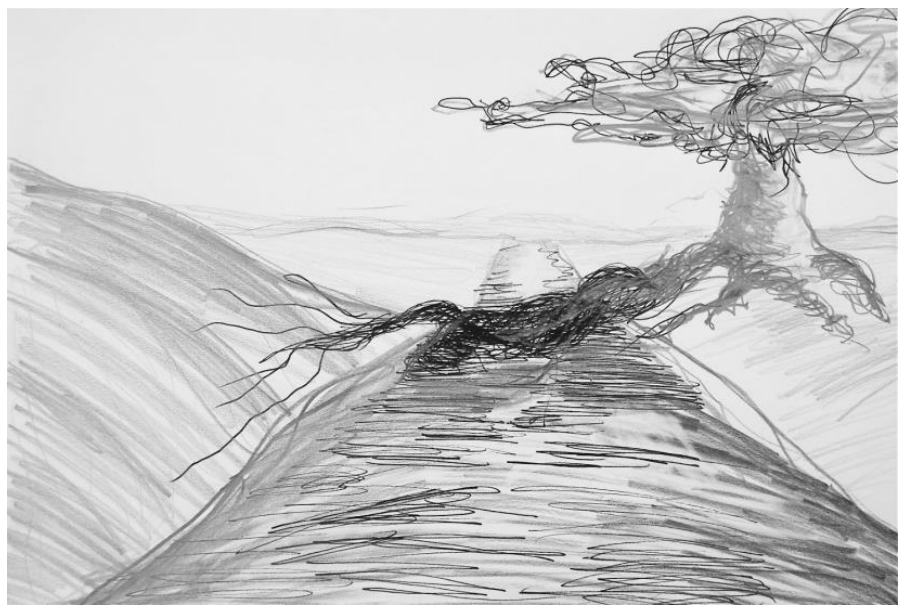

Figura 12. 15 de janeiro de 2013. Fala de Érico: "essa raiz está atravessando a estrada. Ela cresceu". Considerações de P.: neste desenho a raiz de uma árvore está aumentada e destacada pela cor mais forte, além disso, encontra-se no trajeto de uma estrada. A analogia com passagens psíquicas profundas, originais, sugere evidência de conteúdos arcaicos, "no meio do caminho", passíveis de observação e de cuidado no plano consciente. 


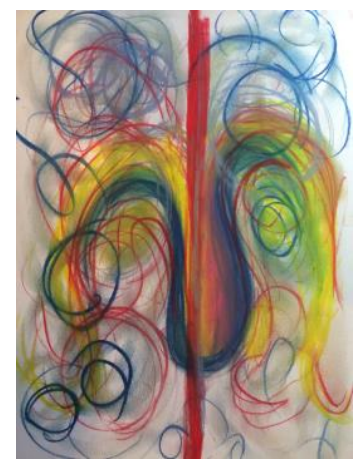

Figura 13. Fevereiro de 2013. Fala de Érico: "fora do eixo. Sempre há dois caminhos, talvez um mais desafiador e outro menos, mas sempre um ou outro eu tenho que percorrer". Considerações de P.: nesta produção as linhas circulares não rígidas e em movimento são divididas ao meio, sinalizando uma forma de separação, lembrando a diferenciação de opostos. Érico pode estar vivendo situações em que tem que escolher e, portanto, afirmar os valores sobre os quais o ego se baseia.

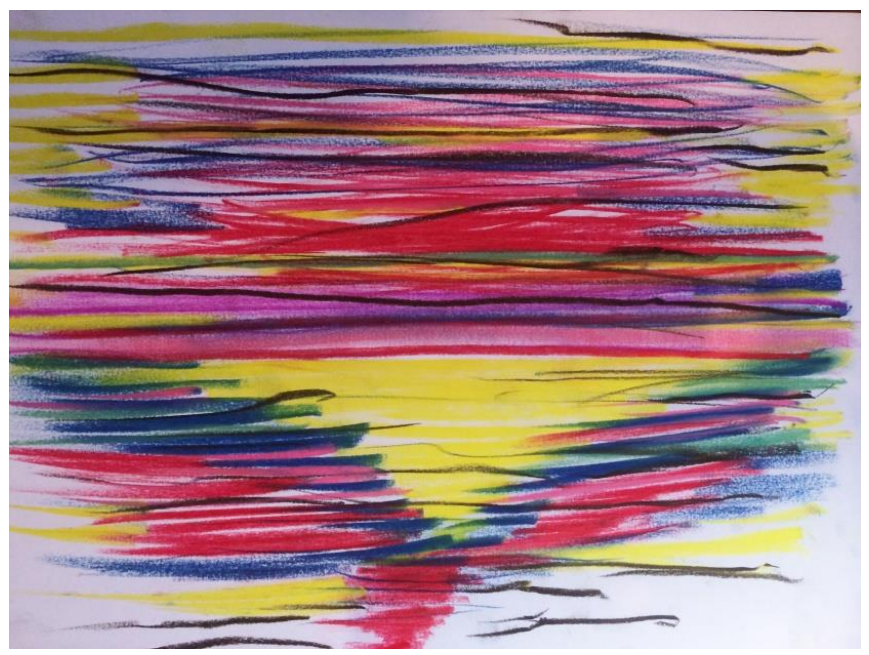

Figura 14. Fevereiro de 2013. Fala de Érico: "linhas soltas, traços coloridos, pressionados, pelo giz e sobrepostos". Considerações de P.: os traços estão, nesta produção, misturando diversas cores. Há uma predominância do amarelo, no meio, o que pode sugerir tanto a falta de diferenciação (caso as cores não tenham sido sobrepostas) como um começo de diferenciação. 
Érico vê essa imagem (Figura 15) como libertação, a psicoterapeuta a vê como continência. A diferença das visões pode sugerir possibilidades do mesmo símbolo. $O$ continente psíquico pode estar permitindo a libertação de Érico. É também possível que esteja acontecendo uma experiência de libertação da grande mãe pelo ato de voar. Érico a vê como um pássaro, querendo voar. A produção sugere outras possibilidades, pois tem na sua estrutura um continente, semelhante a um útero. A psicoterapeuta sugere a visualização da imagem de outro ponto de vista: como um útero, do qual pode se desprender uma ave, ou assemelhado. $\bigcirc$ paradoxo desta produção nomeadamente relaciona os temas continência e libertação. Talvez a mãe boa, a experiência de continência com liberdade, possa permitir a Érico vislumbrar seu desejado voo.

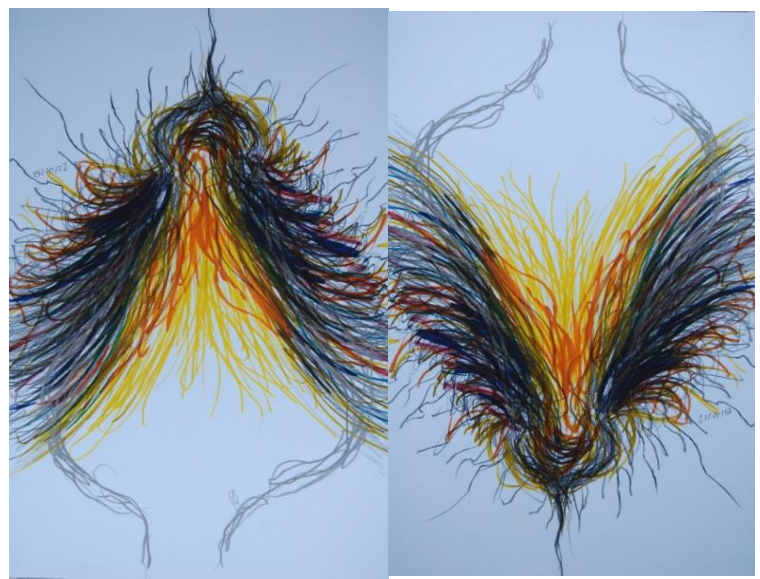

Figura 15. Fevereiro de 2013. A imagem à esquerda (Figura 15A) está na posição em que é vista por Érico. À direita (Figura 15B), outra forma de ver é sugerida por P. Fala de Érico: "eu vejo um pássaro aqui, querendo voar. Finalmente, parece que ele pode voar". Considerações de P.: a $15^{a}$ (primeira da díade composta pelas Figuras 15 e 16, duas produções feitas na mesma sessão) produção traz cores diversas, pela primeira vez. A imagem apresenta um continente e, na parte externa, elementos como fios ou penas que podem se desprender dele ou protegê-lo.

Pelo fato de se tratar de uma díade - duas produções feitas na mesma sessão -, recomenda-se a observação do conjunto, sendo que a Figura 16 sugere oposição à Figura 15. Na primeira produção, as linhas estão grudadas a um continente; na Figura 16 estão livres. Ambas as situações devem estar presentes em Érico, mostrando dois aspectos da mesma questão: em um momento livre, em outro preso. 


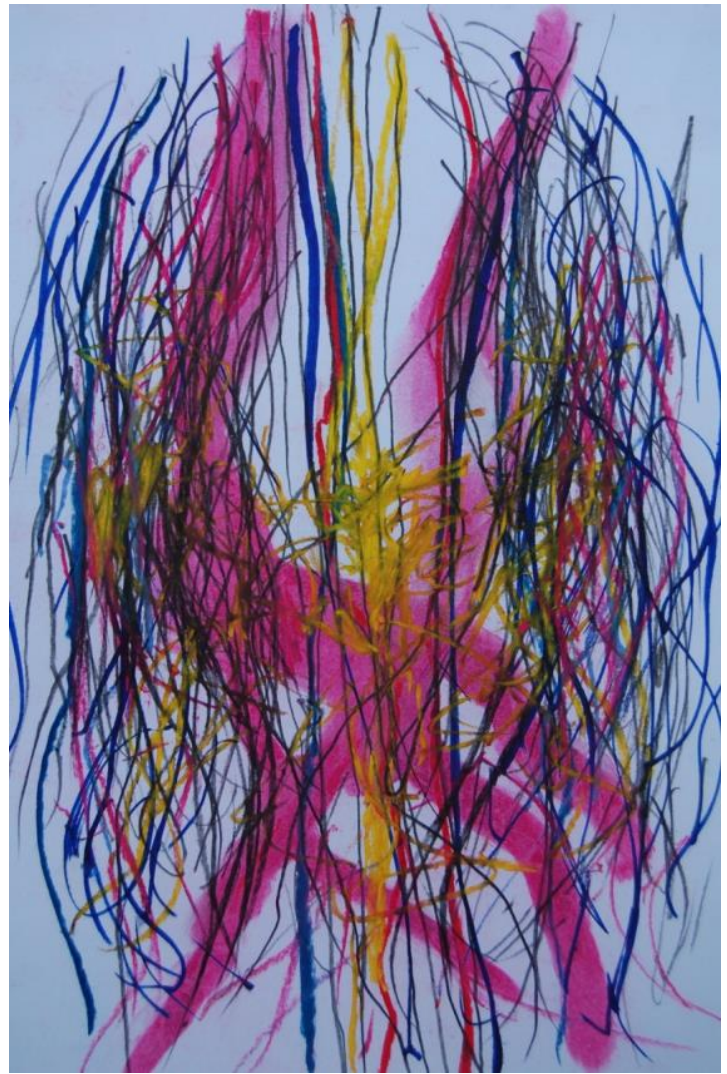

Figura 16. Fevereiro de 2013, segunda da díade composta pelas Figuras 15 e 16. Fala de Érico: "eu vejo com muita alegria esses coloridos. Um movimento intenso". Considerações de P.: aqui as cores novamente aparecem com intensidade, em inúmeros riscos que de novo aludem a cabelos, teia ou rede. A presença do feminino é sugerida nesta produção, agora de maneira fluida e livre.

Em seguida surgem cores no processo expressivo de Érico. Pela primeira vez, o número três aparece na produção de uma tríade: três pinturas (Figuras 17 19). Depois do vermelho, que é sua cor preferida, pinta o azul, que é novidade para ele. Sugerimos que o azul seja representante do mundo mental e espiritual, associado simbolicamente ao céu. Essa dimensão mais abrangente e delicada permite o distanciamento para a visão em uma nova perspectiva. Permite, portanto, o alcance de um sentido para a vivência. A última produção liga o vermelho e o azul, o que indica ligação de polaridades, e dois âmbitos (carnal e espiritual) antes separados. 


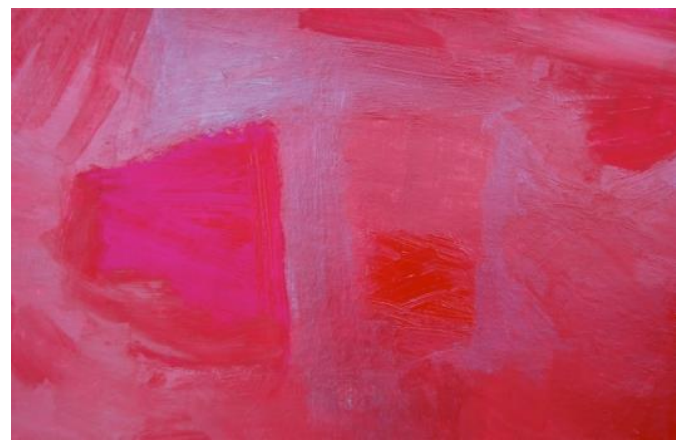

Figura 17. Fevereiro de 2013, primeira da tríade composta pelas Figuras 17, 18, 19.

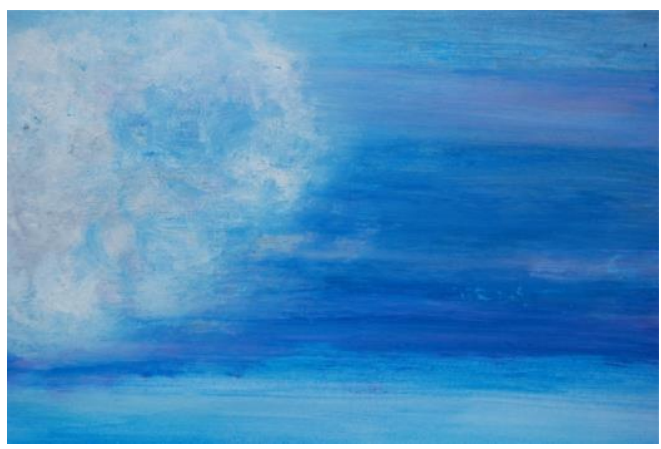

Figura 18. Fevereiro de 2013, segunda da tríade composta pelas Figuras 17, 18, 19. Fala de Érico: "acho lindo essas cores. O vermelho é a minha cor. O azul apareceu, não costumava aparecer. É lindo também. As três estão juntas nessa última produção, achei muito bom".

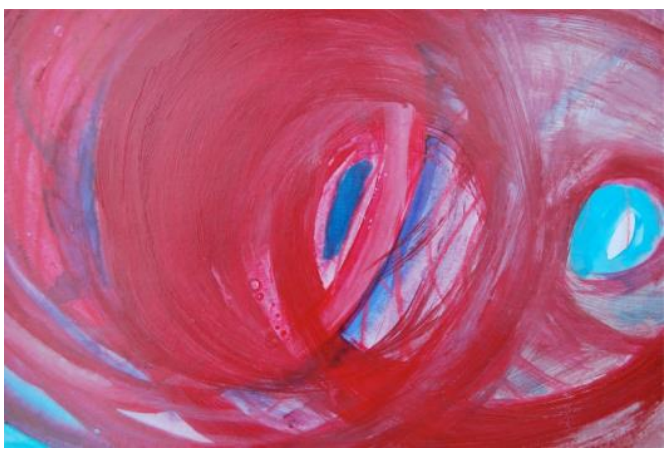

Figura 19. Fevereiro de 2013, terceira da tríade composta Figuras 17, 18, 19. Considerações de P.: esta tríade indica a superação das polaridades, em algum nível do psiquismo de Érico. Ao tratar das cores, observa-se uma aproximação entre emoções básicas. O vermelho, com o qual Érico se identifica desde criança, é o primeiro a aparecer. O azul aparece em sua plenitude, na segunda produção. Há emoções novas, experiências diferentes na vida de Érico. Na terceira produção, observa-se que ambas as emoções podem se integrar. Tanto a aparição do azul como sua integração ao vermelho apresentam novidades na psique de Érico. 
A tríade das Figuras 17, 18 e 19 traz um símbolo denso, com inúmeros desmembramentos. Em a "Interpretação Psicológica do Dogma da Trindade", Jung (1988) organiza um conjunto de ideias interessantes sobre como e por que a trindade é um elemento essencial na religião cristã, segundo padrões psicológicos. Inicialmente, o autor discorre sobre as diversas aparições da figura trinitária, porém, única em diversas religiões da antiguidade. Depois, ele tenta responder porque Deus é trino e não uno ou duo. Por que esse arquétipo é representado por três pessoas e não uma ou duas? Para explicar isso, o autor lança mão de conceitos filosóficos, mostrando que, segundo os gregos, o número "um" ainda não é considerado um número sem o "dois", pois sem o "outro" não há contagem. Assim, Deus não poderia ser uma pessoa somente. Já o número dois é a representação do oposto, do outro, do contraste entre o bom e o mal. A tensão entre o "um" e o "dois" leva ao número "três". A eterna indeterminação do binário se resolve com um terceiro elemento. $\mathrm{Na}$ matemática, somente com três pontos é possível se formar um polígono, ou seja, uma figura com uma área significativa, enquanto que com dois formase somente uma reta. É no número três que aparece pela primeira vez um começo, um meio e um fim. Essa superação das polaridades começa, pois, a acontecer na psique de Érico.

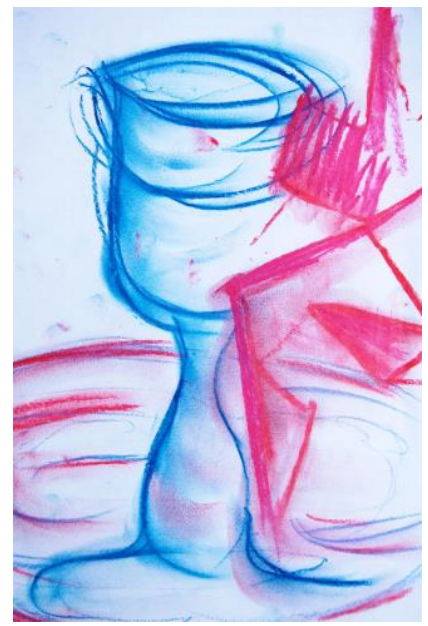

Figura 20. Fevereiro de 2013, primeira da tríade composta pelas Figuras 20, 21 e 22. Considerações de P.: há duas cores, a do copo e a do vinho. O copo, o continente, é azul. O vinho é vermelho. O azul é uma cor que começa a aparecer para Érico e remete a razão e/ou espírito. De fato, tanto a função pensamento como a dimensão espiritual pareciam distantes de Érico até o momento. 


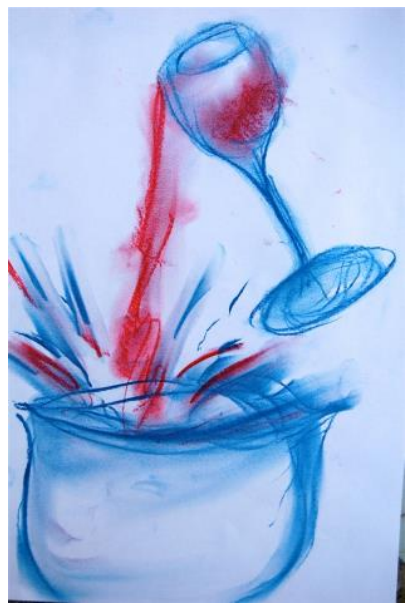

Figura 21. Fevereiro de 2013, segunda da tríade composta pelas Figuras 20, 21 e 22. Fala de Érico: "ontem eu tomei vinho e fiquei admirando a beleza das taças, do vinho, e do reflexo na luz. Estou curtindo essa fase". Considerações de P.: tríade - dois elementos e a resultante de sua união. Temas principais: azul mais vermelho, alquimia, Dionísio. Acontece uma integração de polaridades. Há um continente para receber o vinho que cai do copo. Este continente é uma bacia azul. Tanto o simbolismo ligado à bacia (feminino) como ao azul (razão e espírito) são novidades na expressividade de Érico. O continente agora parece ser confiável e permite a transformação psíquica. A alquimia está sugerida nessa produção, pela união do vermelho com o azul no vaso.

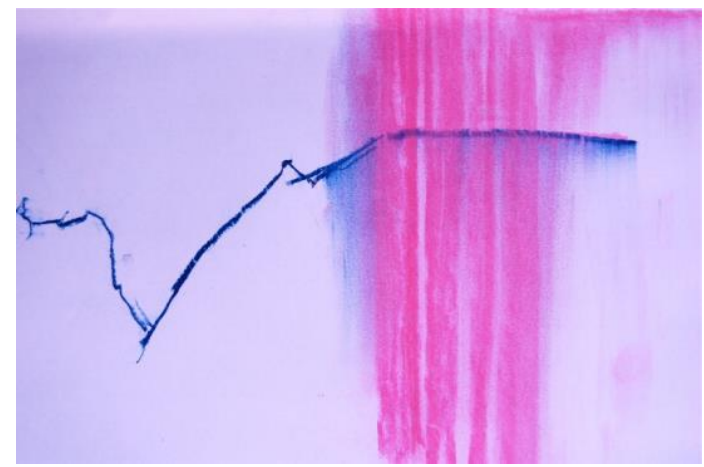

Figura 22. Fevereiro de 2013, terceira da tríade composta pelas Figuras 20, 21 e 22. Considerações de P.: aqui o caminho para transcendência da dualidade é sugerido. $\mathrm{O}$ azul rasga a parede, e o vermelho escorre por ela. Novamente o azul está em local permanente, sólido, e o vermelho fluindo. Aqui não há continente, mas um rasgo, onde as duas cores podem se fundir. O rasgo sugere quebra, ferida psíquica, neste caso associada à parede que é a parte estável da composição. Há, portanto, mais uma sinalização de que houve uma ruptura psíquica possivelmente uma falha ou ferida na experiência. Esta ruptura pode ser a maneira, o caminho de unir aspectos antes separados na psique de Érico. 
As figuras que trazem taças e o vinho carregam também o tema de Dioniso. Érico é um tipo dionisíaco, como abordado anteriormente, e essa expressão permite que tome contato com sua natureza, ligada ao prazer carnal e espiritual. A união do azul com o vermelho mostra aqui mais uma vez o contato com dimensões distintas do psiquismo e sua possível ligação. A última produção (Figura 22) mostra uma fissura e por ela a possibilidade de união do vermelho com o azul. Mais uma vez a quebra - a ferida psíquica pode ser a porta para a união de polaridades em Érico. Na prática, essa é uma forma de tomar contato com sua natureza e permitir que se fortaleça pela experiência.

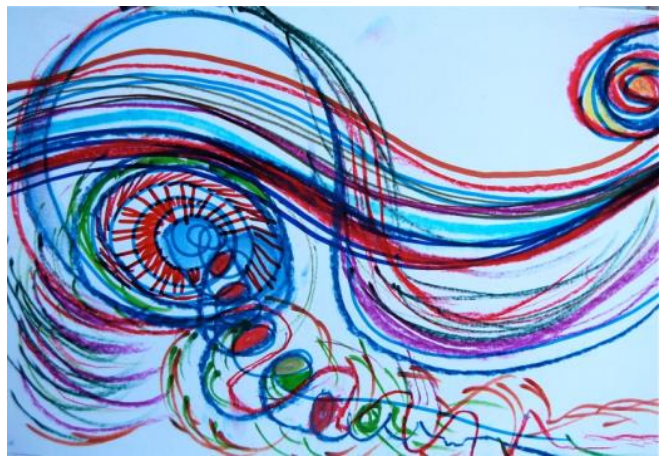

Figura 23. Abril de 2013. Fala de Érico: "achei bonito isso: muitas cores, movimento. Algo apareceu". Considerações de P.: a produção começa a revelar um movimento que antes não existia nas produções de Érico. A partir de um círculo representado à esquerda sai uma espiral, trazendo um movimento possível de transformação.

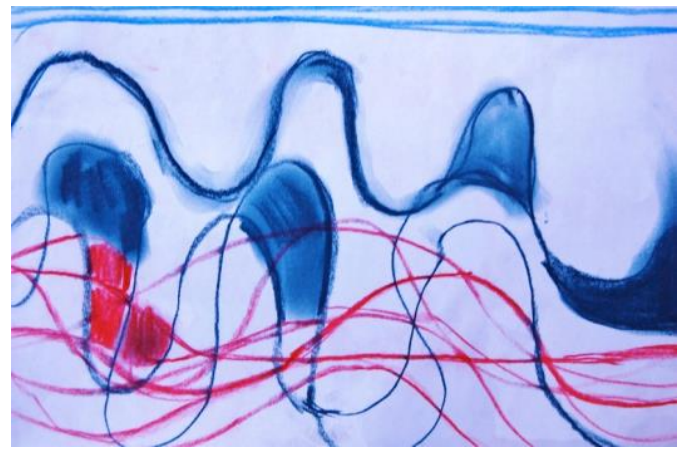

Figura 24. Abril de 2013. Fala de Érico: "achei bonito o movimento". Considerações de P.: o movimento existe em ondas. Alguns espaços começam a ser preenchidos por cores. A vivência do movimento psíquico se apresenta e também o início da relação entre eles. Aqui não há união de cores e não se sabe o que os grupos de cores podem simbolizar. 
Muitas produções seguiram-se a estas, multiplicando as possibilidades de movimento e cores. Na produção 25 (Figura 25) aparece um corpo com duas aberturas ressaltadas (no coração e na cabeça) e muitos balões elevando o corpo - novamente o tema da ferida é retomado. A possibilidade de voar, de sair do concreto se destaca, ao lado do contato com centros de dor e de força (que foram entendidos como possíveis referências a complexos). Estes últimos estão ligados ao coração e à cabeça (a hipótese de que se relacionem com o afeto e o pensamento). Conforme já havia sido suposto, as dores de Érico aparecem com as experiências afetivas e com o exercício intelectual. Quando se toca nas suas feridas e pode-se compreendê-las de novas maneiras, dá-se a chance para o complexo se "despotencializar". Nesse sentido, a imagem dos balões é clara, quando mostra algo saindo do coração e da cabeça.

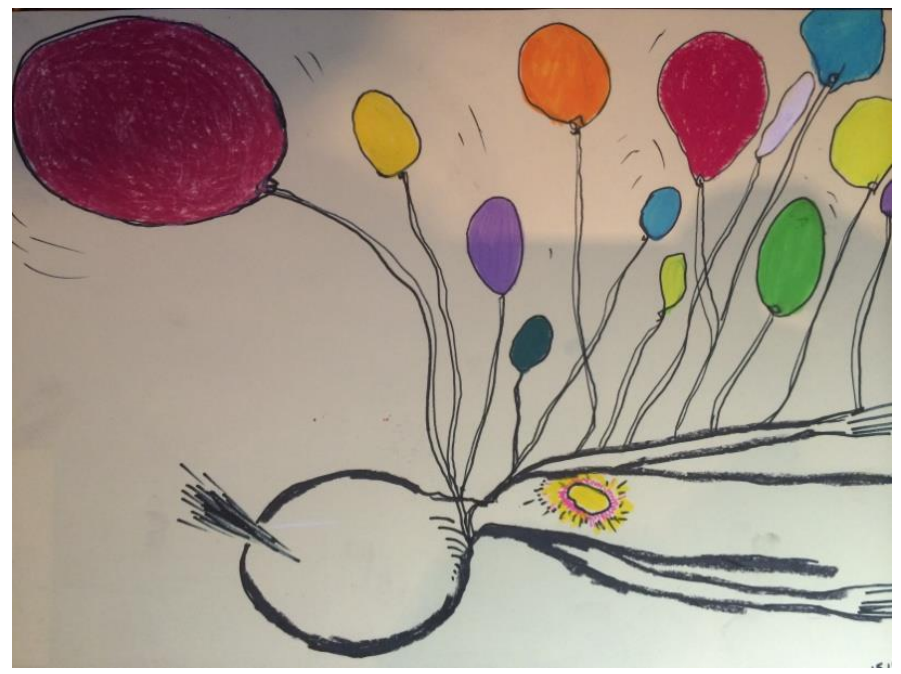

Figura 25. Maio de 2013. Fala de Érico: "esses balões parecem levar o homem para algum lugar. Não há dor. Achei colorido e legal, voar". Considerações de P.: a diversidade de cores indica a expansão das experiências emocionais de Érico. Aqui os balões permitem ascensão, o voo, o ato de se desligar da realidade concreta. Esse movimento mostra a realização de um dos desejos de Érico. O local do coração está ressaltado, em amarelo. Na cabeça há algo que sai ou entra. Ambos os locais podem mostrar feridas; por outro lado, revelam aberturas, espaços de troca. 


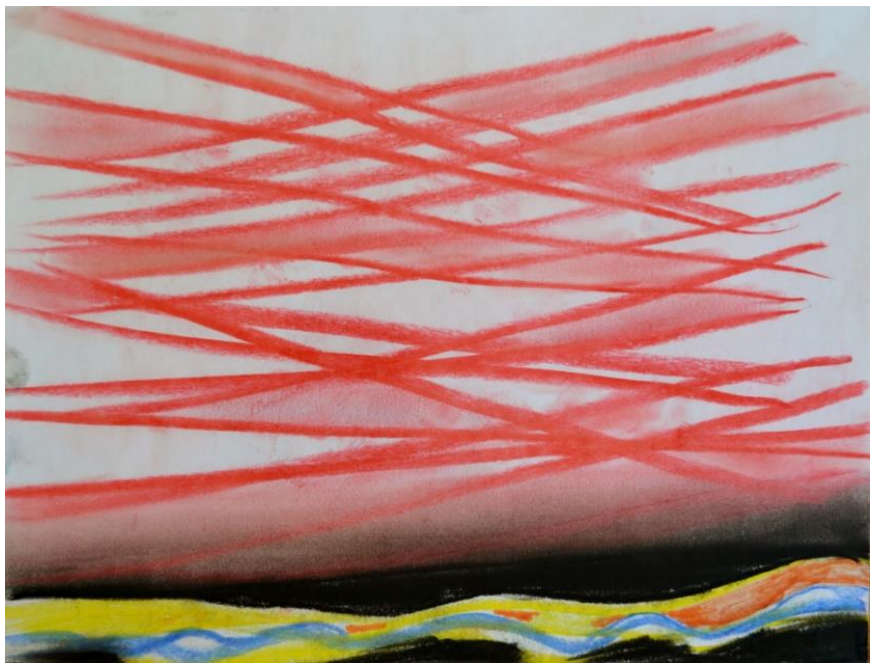

Figura 26. Junho de 2013. Fala de Érico: “não sei, achei legal. Parece que há dois mundos, um em cima, outro embaixo". Considerações de P.: de fato, a produção de Érico apresenta uma parte superior diferente da parte inferior. O movimento na parte superior é reto, com intersecções entre as retas. O movimento da parte debaixo é fluido, com mais cores. Aqui duas dimensões distintas são representadas.

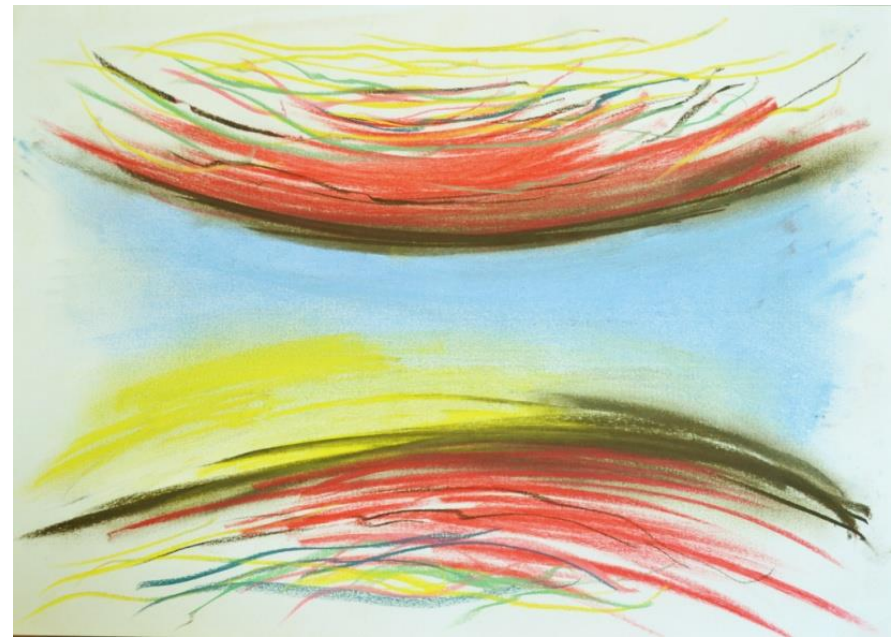

Figura 27. Junho de 2013. Fala de Érico: "gostei desta produção. Parece um canal". Considerações de P.: esta produção parece representar um canal, uma passagem, ou um rio. Ao se relacionar a produção anterior a esta, identifica-se que a mesma imagem pode estar sendo expressa de dois pontos de vista diferentes. O azul e o amarelo referem-se à parte central do canal e o vermelho refere-se à parte externa. Os conteúdos associados à cor azul passam, portanto, a ocupar o centro de atenção das produções. 
Érico é chamado para uma entrevista em uma organização não governamental para o cargo de professor de artes, com um salário de $R \$$ $1.500,00$ por mês. Sente-se humilhado com o salário, acha que subtraindo seus gastos não sobraria nada para si e recusa o emprego.

Em meados de maio de 2013 tem relações homossexuais esporádicas enquanto estava casado. A esposa descobre o fato e o acusa de traidor e homossexual. Érico fica muito chateado porque até então não tinha feito nada disso e esteve em abstinência sexual por anos. Envergonha-se de ter tido relações homossexuais e acha que $P$. ficaria chocada com o fato; demora muito até ter coragem de lhe contar, pois acha muito difícil falar desse assunto com $\mathrm{P}$.

P. pergunta-lhe sobre como ele se sentia ao ter essas relações e Érico responde que "não foi ruim". Nunca quis, contudo, prosseguir com relações homossexuais e sempre desaparecia. Conta que conversava com homens pela internet, que também tinham desejo por outros homens, e se sente consolado com isso. Érico afirma que existe muita gente na mesma situação, homens casados, com namoradas, e que sentem atração por pessoas do mesmo sexo.

Neste momento da psicoterapia, P. sugere a ele que assista ao filme "As aventuras de $\mathrm{Pi}^{\prime \prime}$ (Lee, 2012). Érico assiste ao filme e volta inebriado. Diz que viu e reviu o filme inúmeras vezes. P. pergunta o que mais the chamou a atenção e ele responde que foi o tigre - a relação do menino com o tigre. $P$. pergunta: "e o seu tigre?", Érico, envaidecido, diz que nunca pensou que tivesse um tigre. P. pergunta qual seria o seu aspecto tigre. Érico responde: "Ah, força, independência, agressividade... Acho que não sou muito tigre não!"

P. pergunta sobre qual a cena do filme que mais chamou a atenção de Érico e ele lhe responde que tinha sido a cena na qual o menino quer colocar a mão na jaula do tigre e o pai o impede e pede que ele veja o que um tigre faz com um carneiro. $\bigcirc$ pai então manda colocarem na jaula um carneiro, que é devorado pelo tigre. A família assiste à cena e o menino tem que lidar com esse ensinamento pelo resto da vida.

Diante desse relato, P. faz a seguinte colocação: "quem sabe essa cena possa retratar diferentes faces de um menino ingênuo que tem que ser protegido pelo pai, que não é ingênuo e sabe cuidar dos instintos com visão da realidade e das consequências? Tem também um tigre que, simplesmente, deseja e precisa realizar seus instintos. A escolha da cena pode relatar um momento chave na sua vida?". Érico responde: "Acho que é perfeito. É exatamente isso. Eu me sinto assim, com medo, mas arriscando, querendo conhecer esse tigre".

$\mathrm{Na} 28^{a}$ produção (Figura 28) o tema do tigre aparece. $\bigcirc$ filme "As aventuras de $\mathrm{Pi}^{\prime \prime}$ (Lee, 2012) havia sido sugerido por P. para favorecer a discussão sobre instinto e espírito. Érico o assistiu muitas vezes e ficou maravilhado com o filme. Chama a sua atenção o tempo, a duração da 
relação do protagonista com o tigre. A imagem do felino sugere que existe um trabalho a ser feito para integrar a dimensão instintiva. Érico começou a aceitar isso em sua vida, com cuidado, mas, ao mesmo tempo, maravilhado com a ideia de que "tem um tigre" na sua personalidade.

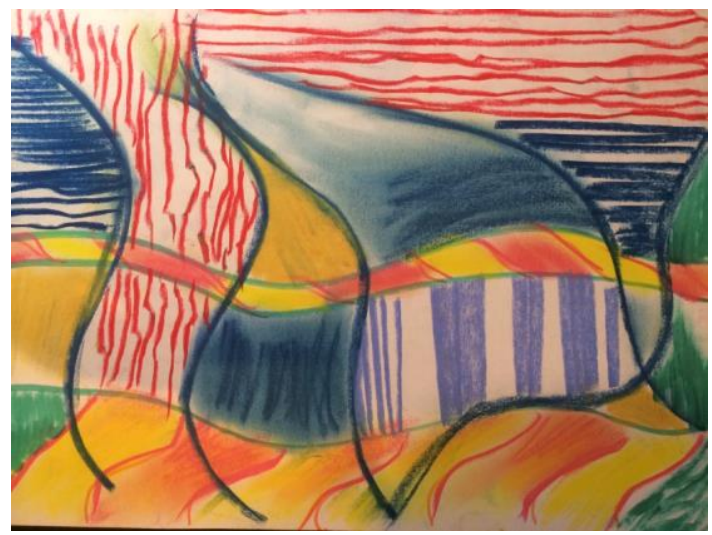

Figura 28. Junho de 2013. Fala de Érico: "essas divisões, para mim, têm a ver com a grade do tigre, do filme "As aventuras de Pi". Considerações de P.: aqui, espaços de intersecção ganham cores e texturas diferentes. O tema tratado por ele é prisão, mas há a exploração de uma série de possibilidades nesses espaços delimitados.

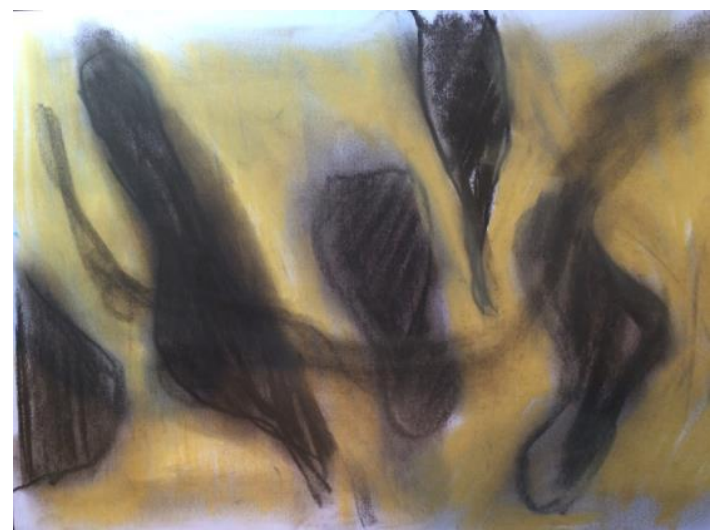

Figura 29. Junho de 2013. Fala de Érico: "aqui as marcas do tigre se expressam com mais clareza. Adorei esse". Considerações de P.: o contato de Érico com o seu aspecto tigre é expresso. Nesta produção, os mesmos espaços de intersecção explorados na figura anterior estão em destaque e as linhas já não aparecem. As marcas do tigre são ressaltadas. 
Em meio a dificuldades financeiras e a uma permanente busca por novos trabalhos, Érico decide arriscar, procurar um lugar para morar sozinho e se separar definitivamente de sua esposa. Um mês depois dessa decisão, Érico consegue um novo trabalho e, em seguida, aluga uma casa por um valor que cabe em seu orçamento. Inaugura-se, assim, uma nova fase em sua vida. As produções (Figuras 30-39) que se sucedem mostram esse novo espaço e a nova alegria de viver.

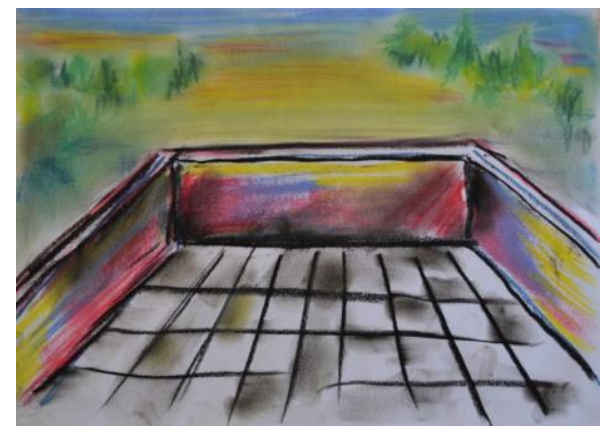

Figura 30. Julho de 2013. Fala de Érico: "este é o meu terraço. Adoro a vista da minha casa nova". Considerações de P.: aqui um novo lugar psíquico é expresso. A capacidade de ver a paisagem à distância. Esta paisagem difere das anteriores porque tem cores. O terraço apresenta as mesmas cores das produções que mostraram o fluxo anteriormente, e tem o quadrado, como novidade.

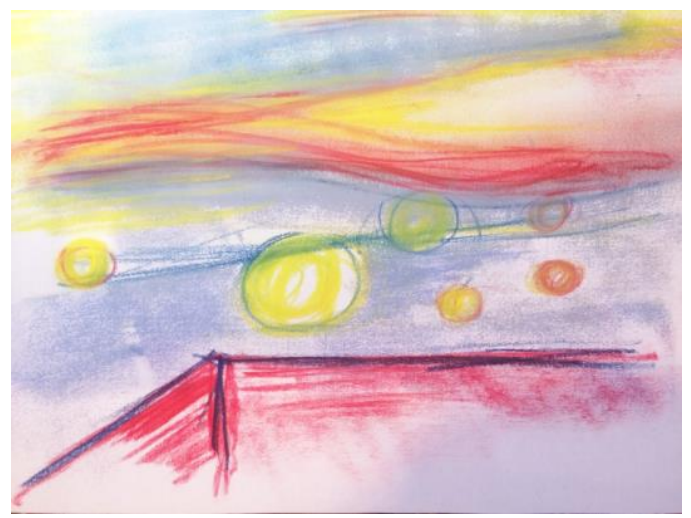

Figura 31. Julho de 2013. Fala de Érico: "é o mesmo terraço. A imaginação voa...". Considerações de P.: aqui o mesmo terraço aparece com cores mais claras e mais vibrantes. O espaço da imaginação está sinalizado com as nuvens e bolas no ar. Este espaço é uma conquista de Érico.

As Figuras 32 e 33 compõem uma díade. Na Figura 33 (a segunda da díade) vê-se um ninho e uma cobra em movimento ascendente, mostrando a liberação de uma energia criativa, a partir de um continente. Estruturalmente 
os complexos materno e paterno não se apresentam mais em sua forma paralisante e destrutiva, e a cobra, um símbolo dos mais complexos, indica movimento ascendente da energia psíquica.

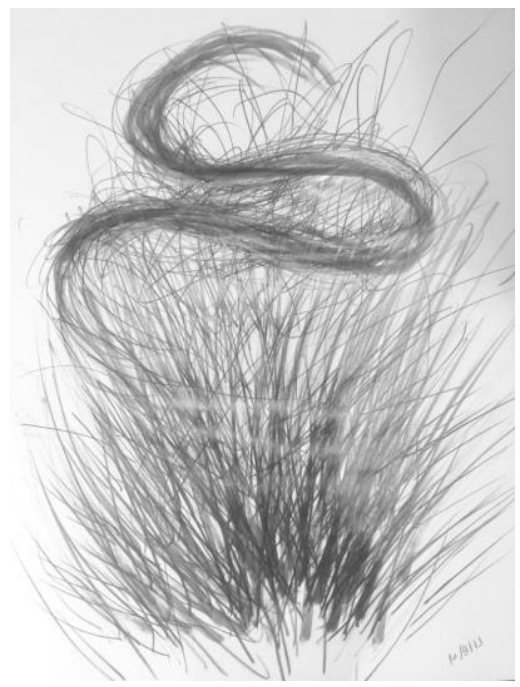

Figura 32. 10 de setembro de 2013, primeira da díade.

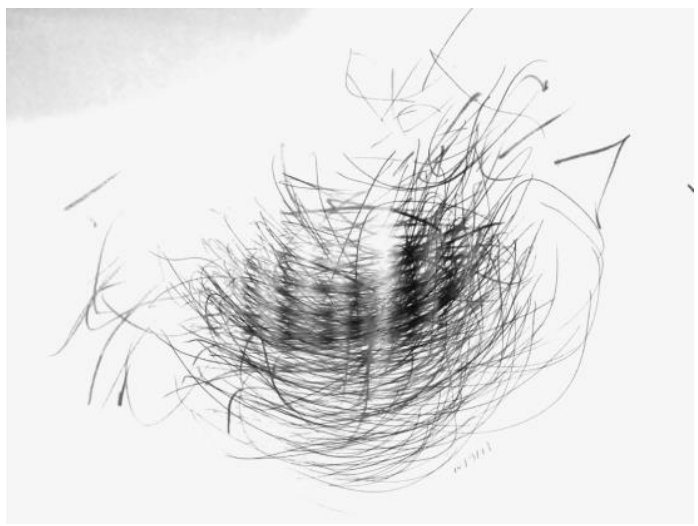

Figura 33. 10 de setembro de 2013, segunda da díade. Fala de Érico: "sem título. Estes dois desenhos eu fiz no carro, vindo para cá, nos intervalos em que o carro estava parado no trânsito. Parece uma cobra. O de baixo, um ninho". Considerações de P.: os fios, pelos, cabelos ou plantas que podem estar representados nos desenhos apresentam-se agora em produções em branco e preto. Um movimento ascendente se destaca da base peluda. Este movimento pode ser associado à cobra ou ao fogo. Inúmeras passagens míticas estão associadas ao fogo, indicando transformação. 
A simbologia da cobra é complexa, mas pode-se afirmar que diz respeito a aspectos primitivos da psique. Ao buscar uma compreensão que evite significados unívocos e reducionismos, pode-se observar o movimento ascendente, como algo que se desprende do campo material para o campo espiritual. Por outro lado, no segundo desenho (Figura 33), o ninho ou o continente aparece. Esse paradoxo, de algo que se desprende do continente, já foi tema de díades anteriores. Esta díade (Figuras 32 e 33) indica que o acolhimento e a ascensão são movimentos paralelos e relacionados. $\mathrm{Na}$ produção seguinte (Figura 34), Érico passa a se identificar e a se dedicar a outras dimensões da vida, incluindo a espiritual, marcada pela presença de um movimento criativo. Ao considerarmos que Érico é bastante ligado à matéria e dificilmente se vincula à dimensão simbólica, esse símbolo revela sua importância.

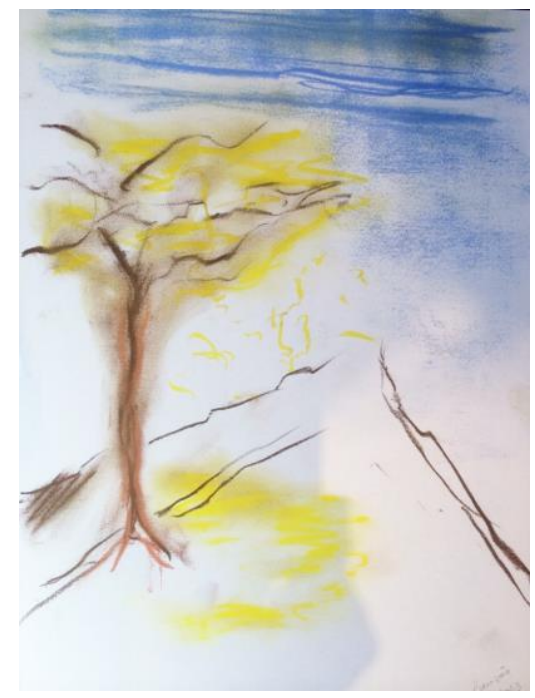

Figura 34. 03 de outubro de 2013. Fala de Érico: "benção". Considerações de P.: aqui uma árvore com flores amarelas aparece em uma rua. Érico comentou que tinha visto uma árvore como esta belíssima recentemente e ficou admirado com a beleza da natureza. A produção apresenta as cores da árvore parecidas com as do tigre anteriormente citado e também um triângulo, que remete ao número três, que vem mostrando a união de opostos.

As produções subsequentes (Figuras 35 a 39) mostram alegria, vontade de dançar. Mostram também uma relação mais livre com as normas e regras, 0 que sugere menos rigidez, ligada ao complexo paterno negativo.

A produção 35 (Figura 35) traz um vulcão. Érico reconheceu que tem forças propulsoras guardadas, que emergem de vez em quando. Ao representar uma força tão primitiva da natureza, como um vulcão, mostrou que esse é um movimento extremamente primitivo, não controlável. 


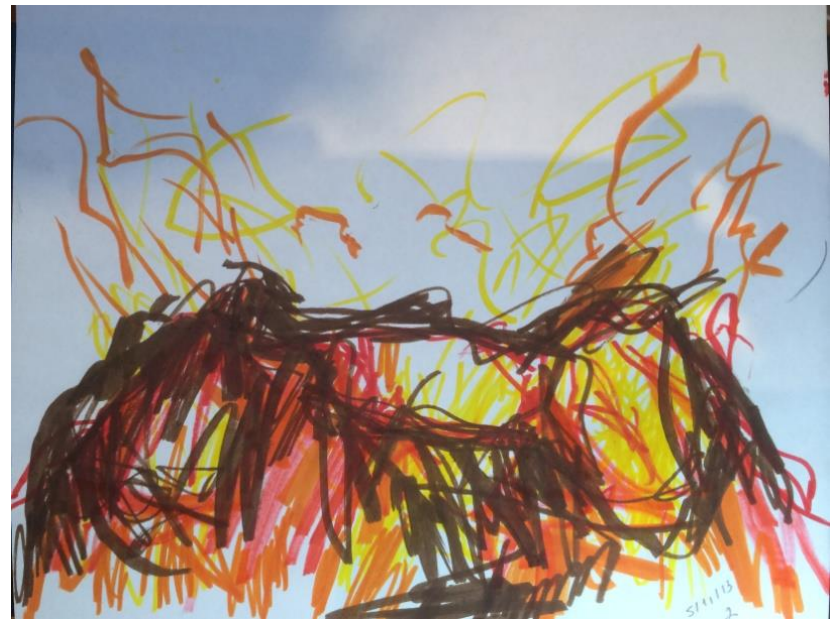

Figura 35. 05 de novembro de 2013, primeira da díade composta pelas Figuras 35 e 36. Fala de Érico: "esses dois desenhos chamam-se 'Vulcão' e 'Festa'. Adoro dançar!" Comentários de P.: os desenhos trazem cores quentes e movimento. O primeiro refere-se ao mundo natural, pelo fato do vulcão pertencer à natureza. O segundo desenho da díade (Figura 36) apresenta muitas pessoas felizes, dançando; remete, portanto, à vida consciente e social.

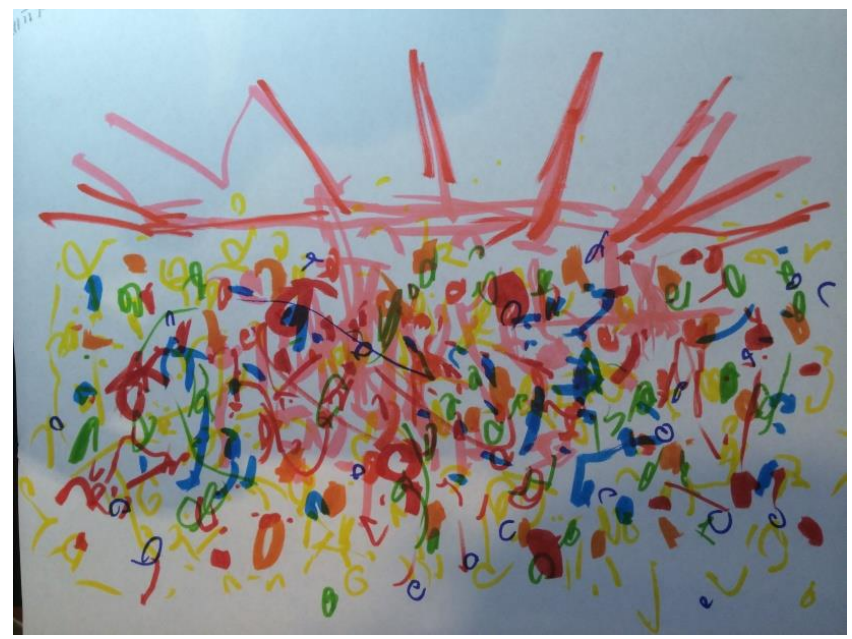

Figura 36. 05 de novembro de 2013, segunda da díade composta pelas Figuras 35 e 36.

Esta díade trata do movimento e de sua aparição em dimensões distintas. A Figura 35 indica a tendência de Érico à quietude, com tendência a erupções, de tempos em tempos. A Figura 36 evidencia a alegria de Érico com o movimento de dançar e de estar no social (que aparece, também, só de 
tempos em tempos). Pode-se tomá-las como expressão de um mesmo movimento, que se apresenta nas dimensões natural e social de Érico.

As produções 37 e 38 (Figuras 37 e 38) trazem pautas. As linhas são vistas como prisão por Érico, que nomeou a primeira produção como "saio da jaula, mas depois eu volto".

A convivência com a regra e com Cronos, o tempo cronológico, é tratada na psicoterapia. O tema do pai arquetípico é, portanto, trazido à tona. Como lidar com adaptação ao mundo real? Érico realizou, na produção da díade das Figuras 37 e 38, imagens que estão em uma festa e ultrapassam os limites da pauta. $\bigcirc$ tema discutido trata de quando e de como dar liberdade aos instintos e de quando e de como conviver com a pauta, a regra. A fala de Érico mostrou receio em relação às experiências afetivas e extrovertidas; ele parece ter receio de se perder nos instintos e de ficar fora da regra.

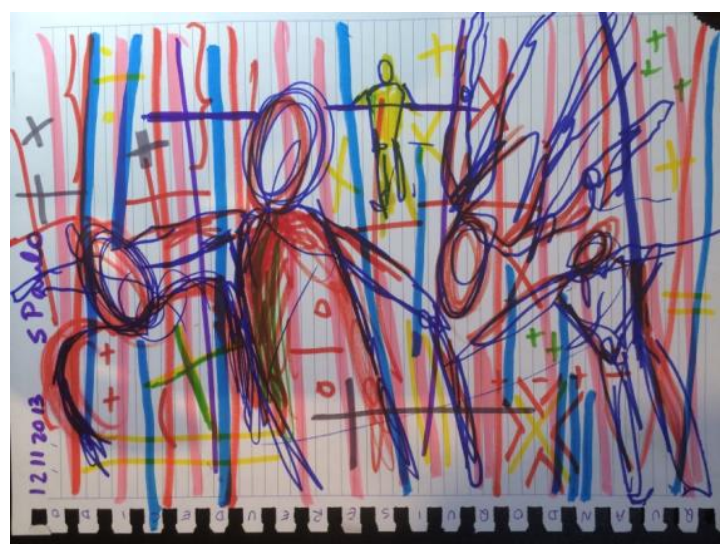

Figura 37. 12 de novembro de 2013, primeira da díade composta pelas Figuras 37 e 38 . Fala de Érico: "é uma festa aqui". Considerações de P.: esta produção sugere um desenho que ultrapassa os limites impostos pela pauta, fato utilizado como parte da comunicação. Érico relacionou a norma, tema relativo ao arquétipo paterno, com as cores diversas, o tema do movimento e da convivência social. Esta produção e a próxima mostram duas relações possíveis com o arquétipo paterno. 


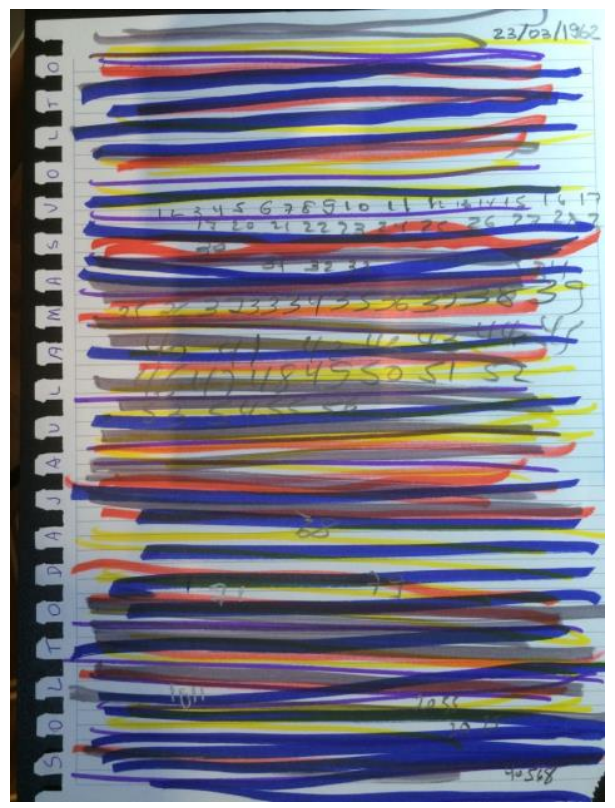

Figura 38. 12 de novembro de 2013, segunda da díade composta pelas Figuras 37 e 38. Fala de Érico: "solto da jaula, mas volto". Humano versus métrica. Considerações de P.: a data descrita é a do aniversário de Érico. Uma sugestão é que associe sua existência ao tema da produção. Aqui as cores, números e letras estão dentro de uma regra. A pauta é usada como parte da produção. Érico fez números e cores de acordo com a norma, "a pauta". O tema do tempo (Cronos) e de espaço lineares sugere respeito ao que é determinado pelo arquétipo do pai.

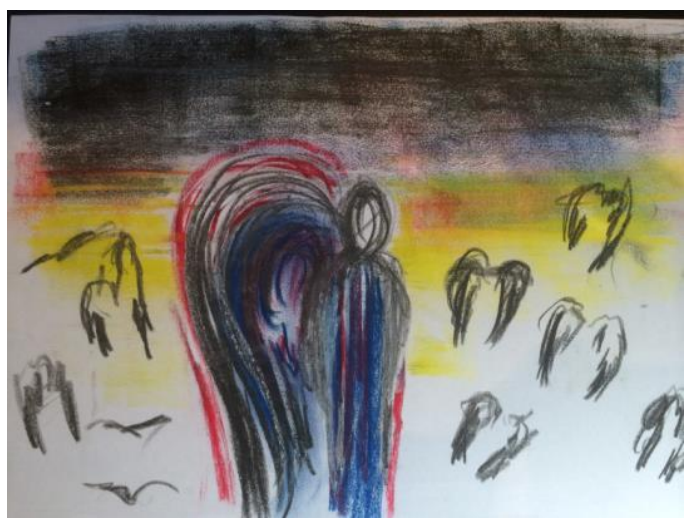

Figura 39. Dezembro de 2013. Fala de Érico: "anjos". Considerações de P.: neste desenho um anjo ao centro é acompanhado de diversos pequenos anjos, no plano mais profundo. Érico afirmou: "adoro anjos". Os anjos são mensageiros do amor (Eros). Hermes, que também tem asas, é capaz de promover a comunicação entre diferentes mundos. A produção indica recursos para "voar", abstrair, e transitar entre os mundos abstrato e o terreno, espiritual e material. 


\section{Tópicos principais de 2014}

As preocupações cotidianas de Érico continuam em 2014, tendo como temas principais o dinheiro e os relacionamentos profissionais. Ele traz para a sessão uma produção (Figura 40), mostrando os movimentos repetitivos da mente consciente, preocupada com o tempo cronológico. Com o título de "Rodamoinho", retrata preocupações cotidianas.

A Figura 40 trata de um momento em que um complexo emerge. Isso se deu porque na escola surgiram conflitos com os alunos, que desafiaram a autoridade de Érico. O retorno da experiência dolorosa foi trabalhado pela retomada de suas passagens familiares, que o colocaram, no passado, na posição de ser o errado da família. Esse "erro" foi revisto, com novos olhares e possibilidades de compreensão.

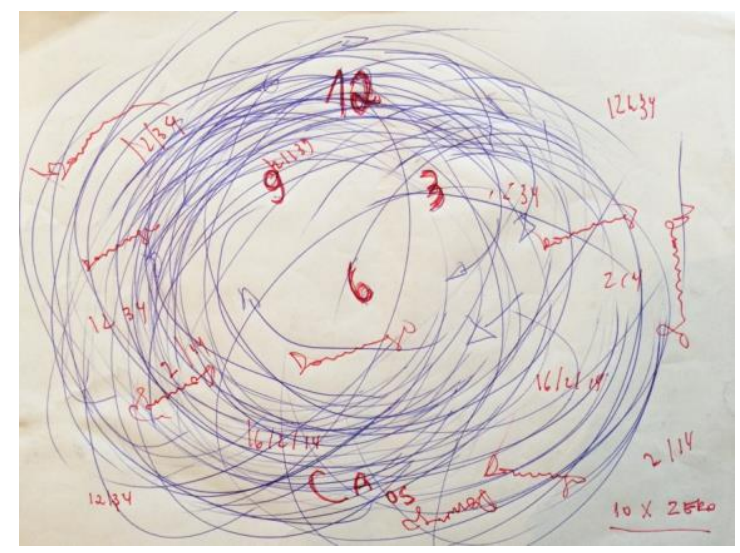

Figura 40. Dezembro de 2013. Fala de Érico: "fiz esse desenho no caminho para cá. É assim que me sinto. No meio de um rodamoinho. Fico tomado por pensamentos repetidos e me sinto sem saída". Considerações de P.: Érico mostrou, aqui, o funcionamento da consciência, quando repete dados em movimentação circular.

Érico sonha em viajar, mas não tem condição financeira para isso. Mais do que viajar no nível concreto, compreende-se que ele deseja conhecer uma forma de viver com mais liberdade e prazer, uma vez que sua vida consciente é repetitiva e penosa (Figura 41). 


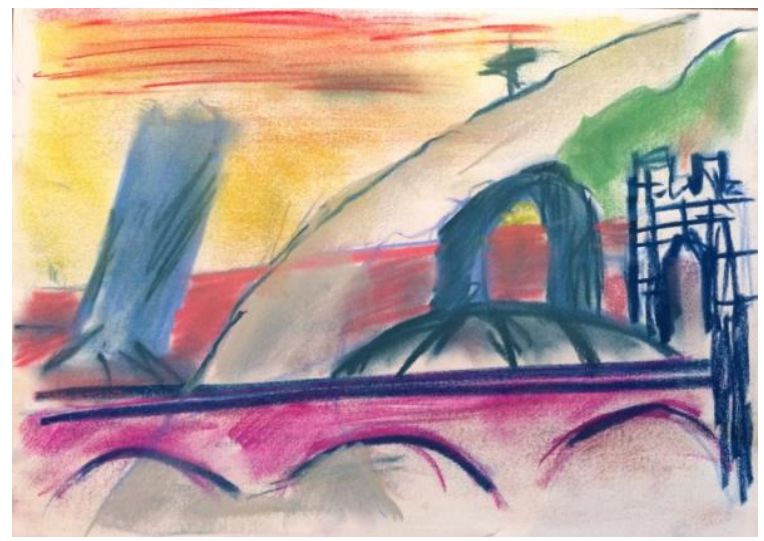

Figura 41. 14 de fevereiro de 2014. Sem título. P. pediu para Érico pensar em um estado mental livre, que gostaria de ter. Érico desenhou na sessão esta produção que mistura marcos de cidades turísticas, mostrando que gostaria de viajar a diferentes lugares.

No nível mais profundo aparece, contudo, outra sorte de conteúdos. Em um sonho, a casa dos pais é queimada e ele não se sente triste com isso (Figura 42). Revela-se assim a perda de referências antigas, paterna e materna. $\bigcirc$ trabalho psicoterápico começa a se debruçar sobre tal morte, pois, a mudança na forma de enxergar os pais permite que Érico reveja a figura deles de maneira mais compreensiva.

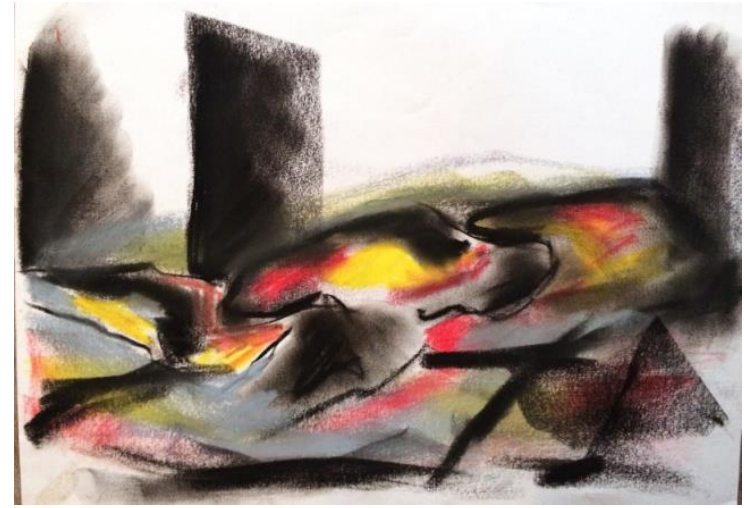

Figura 42. 21 de fevereiro de 2014. Fala de Érico: "esta é a representação de um sonho que tive no final de semana. A casa da minha família estava queimada e eu estava em cima dos destroços e das brasas. Não tinha nenhum sentimento. Apenas constatava o fato". Considerações de P.: a casa da família é a casa psíquica original de Érico. Esse sonho mostra que ela foi queimada, destruída, o que indica a perda de referenciais iniciais relativos aos arquétipos materno e paterno. Érico já não funcionou psiquicamente como no início, com a mesma dinâmica da sua família. 
Com a representação da Figura 42, de um sonho em que a casa da família é queimada, o reconhecimento de que o padrão familiar de julgamento não Ihe pertencia traz satisfação a Érico e a possibilidade de lançar novos olhares e de dar novo sentido a sua existência. Isso se reflete nas Figuras 43 a 45.

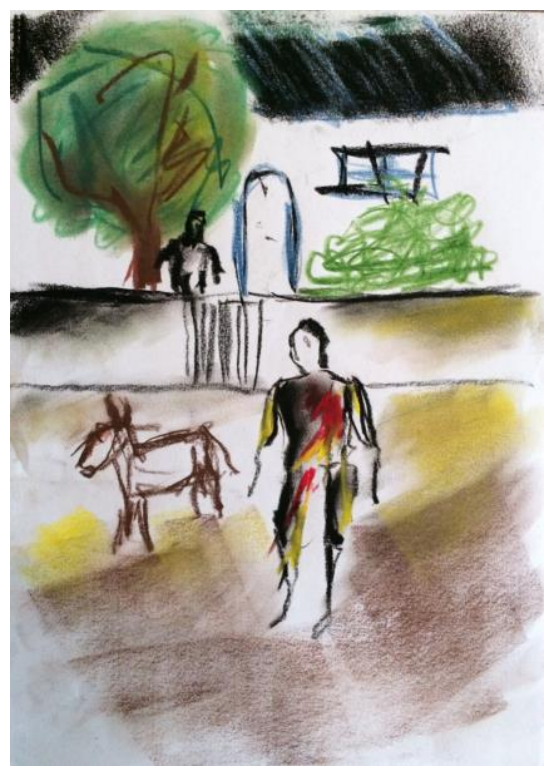

Figura 43. 21 de fevereiro de 2014. Fala de Érico: "esta é a representação da imagem que vi em um pequeno monóculo antigo. A imagem de minha mãe atrás de uma cerca com as mãos na cintura, olhando para mim. Ela estava na frente da casa da minha tia. Eu, no campo, estava do lado de um animal, distante dela". Considerações de P.: esta passagem remete Érico a sua independência da família e a uma frase que sua mãe disse no passado sobre ele: "Esse menino gosta da vida".

A Figura 42 associa-se à Figura 43, ambas elaboradas na mesma sessão. Nesse sentido, as produções apontam para sua relação psíquica com a família nuclear. A Figura 43 apresenta uma novidade em relação à produção anterior: está perto dos instintos, de um animal, no campo.

A Figura 44 revela que Érico, podendo olhar o horizonte, sente-se iluminado de cima para baixo. A luz, representação da consciência e do masculino, que também indica prospecção, uma relação com a consciência e com a dimensão superior. 


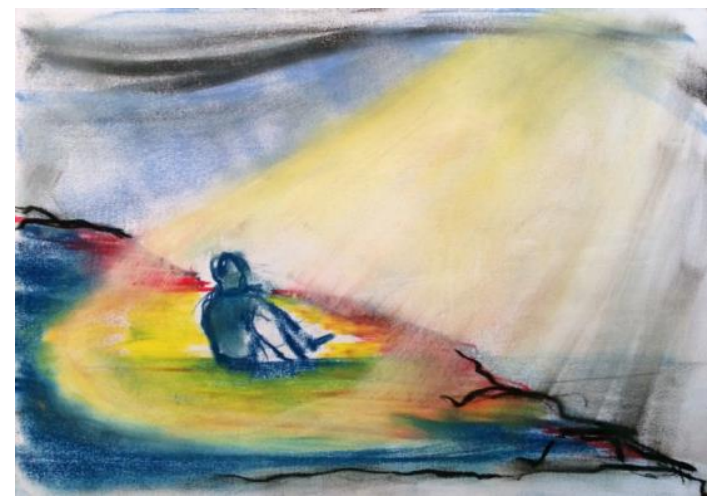

Figura 44. 28 de fevereiro de 2014. Fala de Érico: "eu me sinto assim: iluminado". Considerações de P.: a produção, de fato, mostra um homem iluminado. Essa luminosidade pode estar associada a um contato com o mundo numinoso ou divino, pois vem do alto.

A Figura 45 mostra dois grupamentos de pessoas, um grupo com quatro e outro com duas, sendo que estas estão de mãos dadas. $\bigcirc$ relacionamento humano se apresenta com melhores perspectivas. Além disso, os números "quatro" e "dois" remetem aos integrantes da sua família e indicam que ele não se sente mais de fora, o "patinho feio". A amplificação remete à totalidade (quatro) e às polaridades (dois) que representam um relacionamento humano dialético e inclusivo em curso.

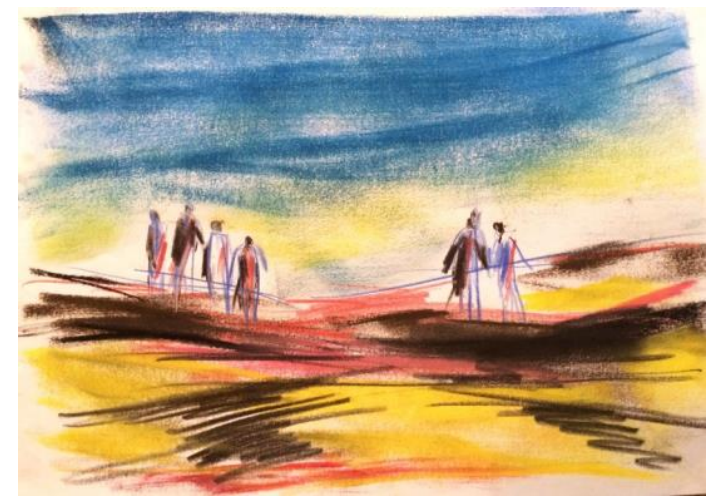

Figura 45. 28 de fevereiro de 2014. Fala de Érico: "aqui eu vejo pessoas olhando o horizonte. Não sei quem são". Considerações de P.: nesta produção as pessoas aparecem em grupos de quatro e de dois integrantes. O quatro é o número de pessoas da família nuclear de érico; é também o primeiro número que se refere à totalidade psíquica. O dois é o número de filhos em sua família, mas também é a representação possível de um casal, que aparece no desenho de mãos dadas. A união (de conteúdos diferentes) e a observação do horizonte (da vida) são indicadas como possibilidades. 
Uma vez transformada, revista e revisitada a psique, em sua relação com arquétipos de base, abre-se para Érico uma nova visão da vida. Ele apresenta esta nova visão na Figura 46 (díade composta pelas Figuras 46A e 46B) - nublada no início, mas com a possibilidade de se clarear.

A Figura 46A retrata um novo sonho. A imagem mostra dificuldades para olhar com clareza o mundo externo. A experiência não incomodou Érico. P. perguntou como ele se sentia sem enxergar com clareza o mundo de fora e ele respondeu que não gostava. Essa passagem é sugerida por $P$. como uma possibilidade de reconhecer outras formas de visão. Érico aceitou a sugestão, mas disse, brincando: "Não gosto da sensação!"

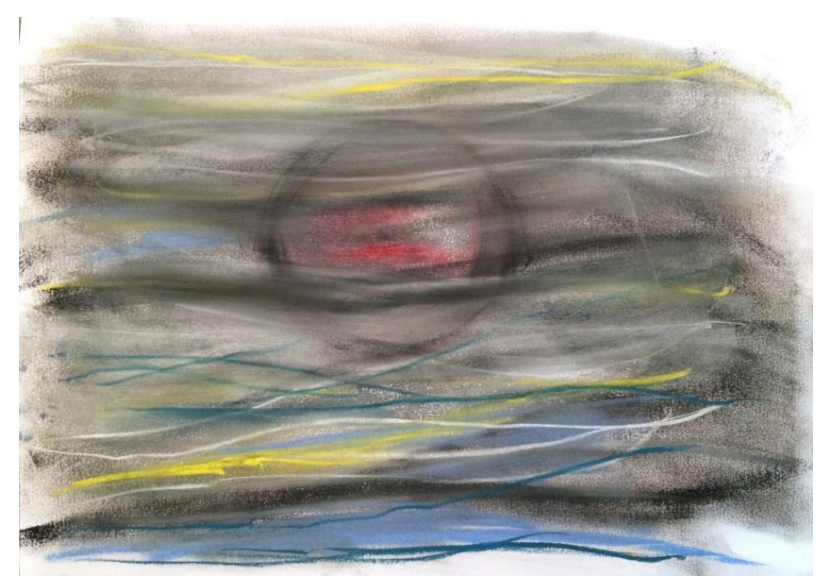

Figura 46A. 12 de março de 2014. Fala de Érico: "esse desenho mostra um sonho que tive. Estava com os olhos um pouco irritados e piscando. Não conseguia enxergar com clareza".

O segundo desenho (Figura 46B) foi feito a pedido de P., após conversa sobre o ato de enxergar. Refere-se ao estado inicial de visão, antes do olho estar embaçado. A produção remete à capacidade de ver, enxergar certos conteúdos. Não se sabe a que conteúdos ela se refere, mas sabe-se que há a perda de nitidez na percepção consciente de algum conteúdo. 


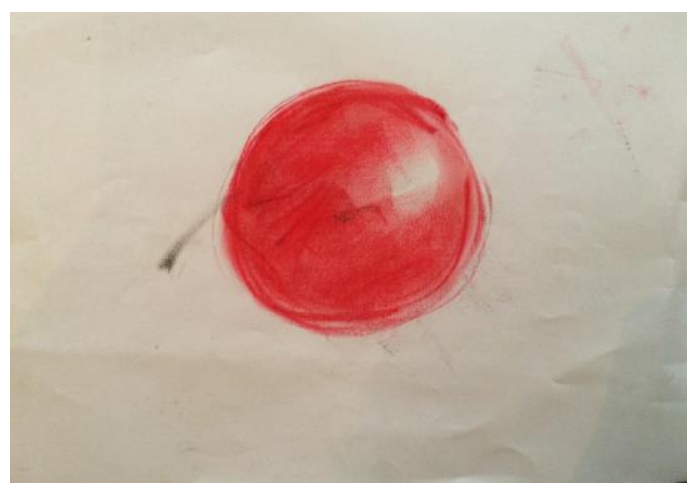

Figura 46B. 12 de março de 2014. Considerações de P.: a figura menor é um detalhe; mostra como começou a produção.

Érico sonha com uma exposição de artes em que há pedaços de carne nas paredes (Figura 47). Ele associa a carne ao sabor, à cor e à textura, provenientes da experiência cotidiana. Acredita que a vida tem mais sabor neste momento. No sonho ele dá um pedaço de carne à ex-esposa, sinalizando uma reconciliação e uma retribuição a tal representação da anima.

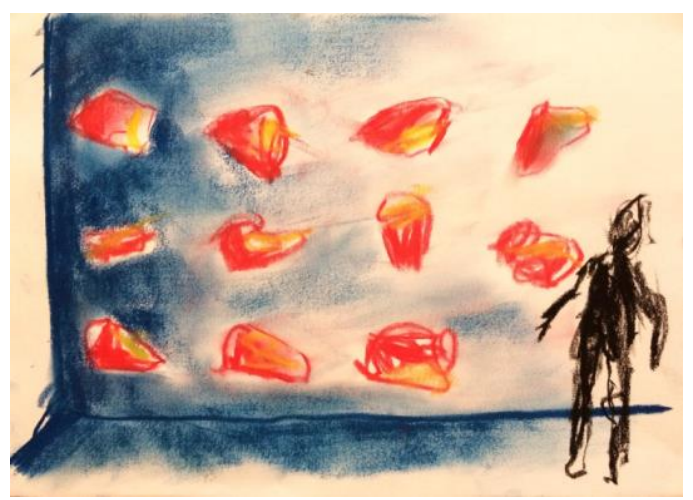

Figura 47A. 19 de março de 2014. Fala de Érico: "essa é uma imagem que tive em um sonho. Entro numa sala de exposição e vejo um monte de carnes dependuradas. Na verdade, aquilo tudo era muito bonito. Escolho três delas e dou para a minha ex-mulher". Considerações de P.: a carne está associada para Érico à textura, sabor, cor. Sinaliza associação ao aspecto carnal, material, da vida. Érico disse que acha que sua vida material pode mesmo estar mais saborosa e bela no momento. Reconheceu que sua ex-esposa the ensinou muitas coisas sobre a vida material. 


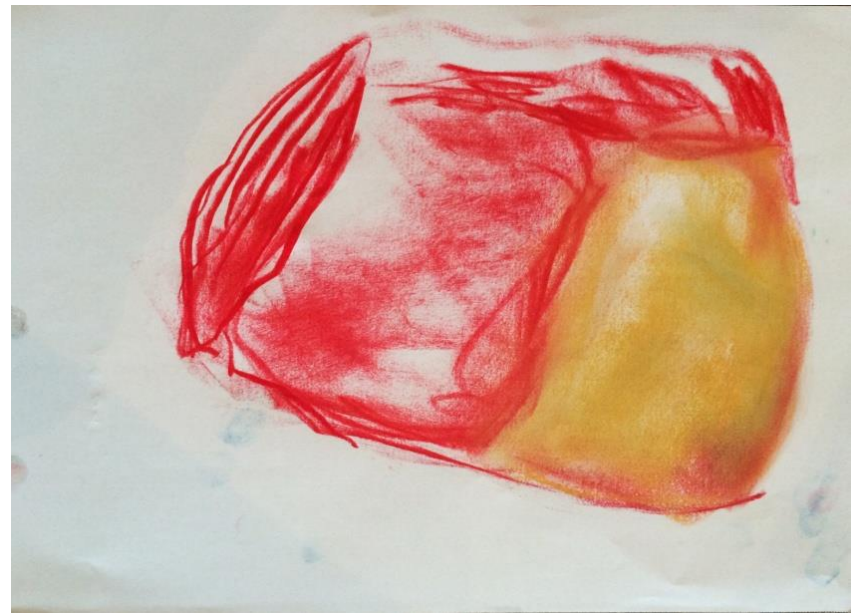

Figura 47B. 19 de março de 2014. Detalhe da produção anterior: pedaço de carne. Considerações de P.: aqui o foco da produção anterior aparece - a carne. Ela é feita de cores vibrantes, as preferidas de Érico. O sonho sinaliza uma reconciliação com os aspectos carnais, materiais da vida, relacionados ao feminino.

Neste momento da psicoterapia, Érico usufrui mais da vida e parece suportar seus desafios com uma estrutura mais forte. Relaciona-se melhor com os colegas e faz amigos. As relações amorosas passam a ser menos ameaçadoras e ele vive uma experiência amorosa homossexual que se estende por alguns meses.

A vida pragmática flui melhor, com trabalho e relações. Não sem conflitos, contudo. Permanece a revolta em relação a figuras de autoridade (como as diretoras das escolas em que leciona) que mentem ou manipulam informações.

Nas figuras 47 e 48, Érico se mostra mais forte, capaz de enfrentar situações de medo e de conflito. 


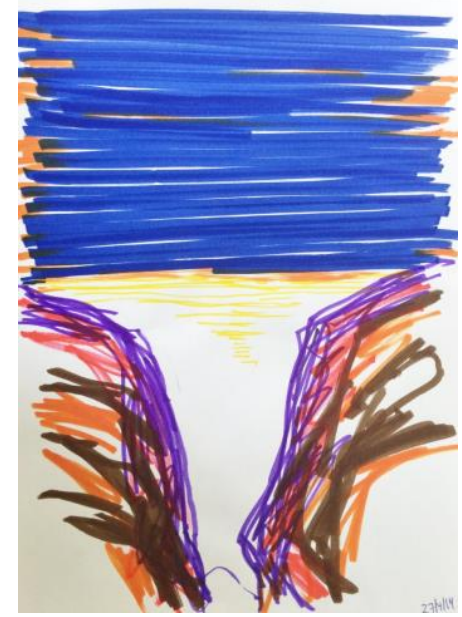

Figura 48. 27 de abril de 2014. Fala de Érico: "sem chão. Um caminho entre duas montanhas imensas e um horizonte azul à frente. Estar neste caminho, entre duas 'muralhas' imensas de rochas, terra, é assustador. Parece que a qualquer momento na passagem elas podem me sufocar e eu ficar preso a elas. Neste momento não posso deixar de observar que além das 'muralhas' há um horizonte azul anil belo, imenso também. A passagem para mim implicou um medo em minha vida, mas mesmo assim avancei. O que não sabia é que nunca recuei. O medo poderia me intimidar, mas nunca desisti". Considerações de P.: Érico vê duas muralhas e um horizonte azul à frente e hoje se sente mais forte do que no passado para trilhar esse caminho de enfrentamento, essa passagem. Uma possível amplificação permitiria a associação das muralhas ao arquétipo da mãe e o horizonte azulado ao do pai - transição necessária para o desenvolvimento normal.

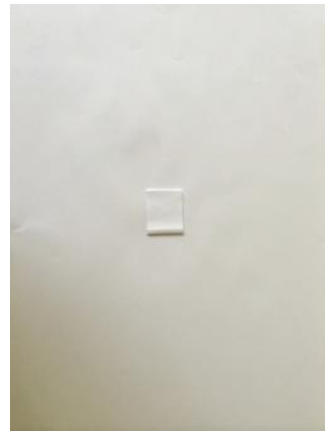

Figura 49. 29 de abril de 2014. Fala de Érico: "vazio. O branco sobre o branco. Dois brancos, em um único vazio? Será que é um vazio absoluto? Mas a sensação é. Me sinto vazio, não preenchido, com lacunas imensas no ser, espaços em branco. Eles me fazem ficar mais leve, mas talvez a racionalidade queira preenchê-los". Considerações de P.: a diferenciação do branco da folha para o pequeno pedaço de branco ao centro é pequena. Sugere que conteúdos do self em sua diversidade necessitam serem reconhecidos pela consciência para que a diferenciação da personalidade possa ocorrer. 
Em setembro, Érico adoece de pleurite crônica, uma doença que afeta a pleura, os pulmões. A Figura 50 pode ser observada como uma antecipação disto. Após o seu retorno, mesmo com a doença, Érico se sente mais fortalecido e sofre menos, no cotidiano. Administra fatos concretos com mais praticidade e um pouco mais de distanciamento emocional.

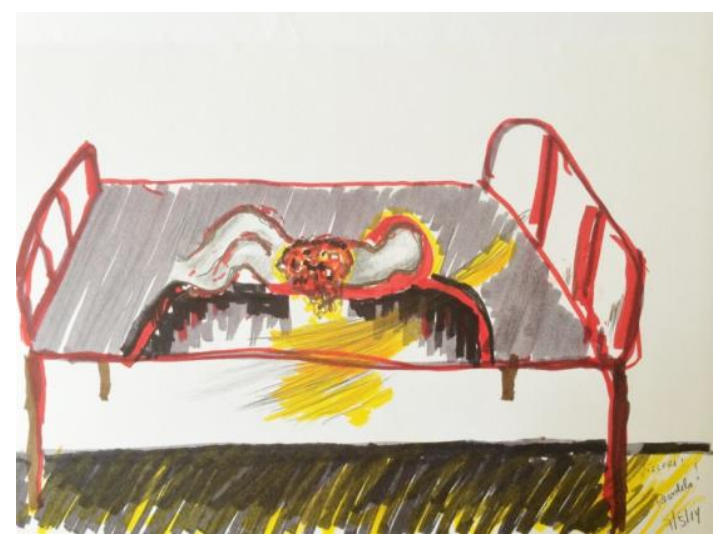

Figura 50A. 07 de maio de 2014. Fala de Érico: "pesadelo, vísceras (expressão de um sonho). Eu em uma cama expelindo minhas vísceras. Algo extremamente assustador, sentir náuseas e contrações observando as vísceras serem expelidas ainda vigorosas e pulsantes. Há uma sombra escura acompanhada de uma luz amarela. Vomitar as dores que incomodam a mim. Me livrar delas num momento caótico de minha vida. Ou elas ficam comigo, no meu interior e dominam minha vida e corpo ou as coloco para fora de meu ser. Apesar de assustador foi uma alívio. Fiquei leve com meu ser". Considerações de P.: Érico se vê em relação com suas vísceras, que têm sombra e luz (o que elas representariam em termos simbólicos?); algo que, ao mesmo tempo, assusta e alivia.

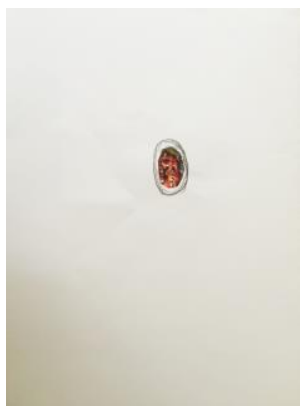

Figura 50B. 07 de maio de 2014. A capa com um furo que deixa ver parte da pessoa representada. 
A produção 51 (Figura 51) mostra um caminho para um horizonte azul. A abertura se apresenta para cima, da forma como Érico a vê. Trata-se, portanto, de caminho ascendente. Nesse momento, Érico não mostrou receio de se relacionar com o novo, que se apresenta tanto no contato com seu mundo interno como no contato com as novidades que a vida pode apresentar. A produção seguinte (Figura 52) apresenta um caminho livre, sólido e seguro e faz alusão ao conhecido, ao ego, à consciência.

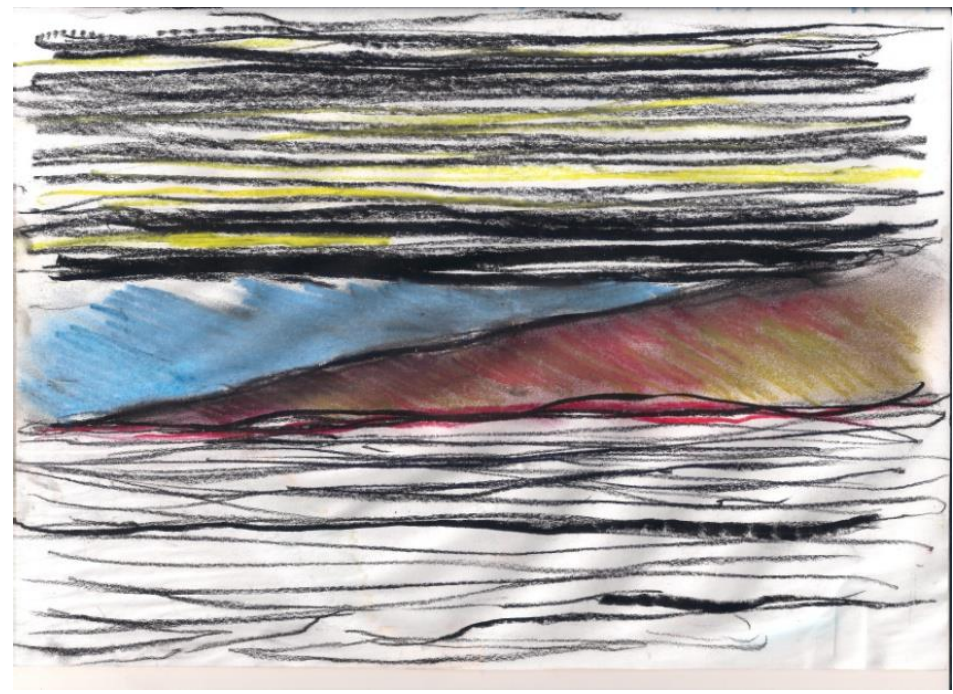

Figura 51. 29 de abril de 2014. Fala de Érico: "contato. Três momentos. Linhas mais retilíneas acima, formas mais palpáveis em vermelho e azul e linhas mais fluidas e leves abaixo. Tenho sempre que tomar decisões, e tenho conseguido ser mais prático dentro do meu limite, pois a ansiedade diminuiu". Considerações de P.: a produção coloca duas cores e dimensões em contato. Tal confronto de opostos requer uma personalidade suficientemente forte e esse parece ser o caminho traçado por Érico: o de suportar mais os confrontos. 


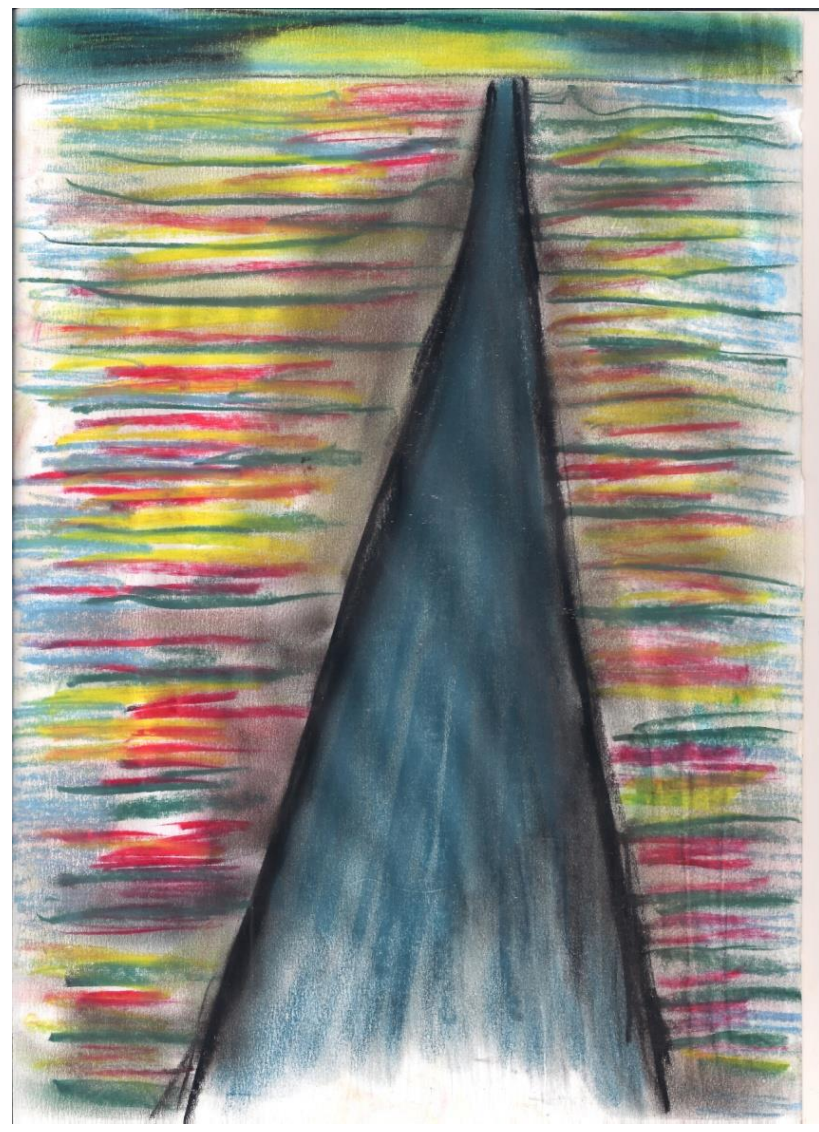

Figura 52. 12 de junho de 2014. Fala de Érico: "caminho estável. Um caminho definido e um sol no final. Sinto-me feliz de ver o sol à frente mesmo sem saber onde vai dar". Considerações de P.: a produção mostra um caminho definido, de uma só cor e a diversidade de cores nas laterais. O tema das produções anteriores é retomado: quanto maior a distância entre a consciência e o que está no inconsciente, menor a integração. Por outro lado, o ego precisa de estrutura para entrar em contato com o desconhecido e com a diversidade. Nesta produção o conhecido é enfatizado, oferecendo tranquilidade a Érico.

A produção seguinte (Figura 53), em branco e preto, traz Érico sendo contido por duas paredes que têm abertura para diversas dimensões externas. Como indicam suas associações, mostra a descoberta ou enfrentamento da necessidade de caminhar sempre entre obstáculos ou passagens livres e fluidas. $O$ fato de serem em branco e preto novamente indica que tratam de aspectos estruturais. Érico mostrou-se mais estruturado nesse momento, para enfrentar obstáculos e possibilidades apresentadas pela vida. 


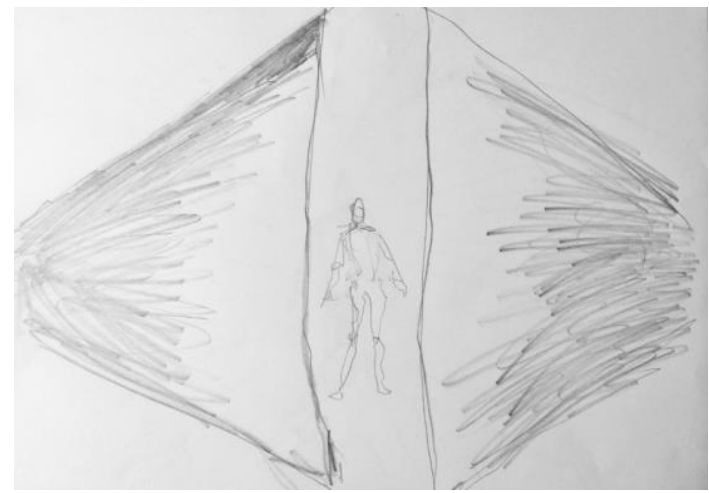

Figura 53. Julho de 2014. Fala de Érico: "sem título. Eu entre duas paredes grandes na saída de um corredor ou percurso. A descoberta ou enfrentamento da necessidade de caminhar entre obstáculos ou passagens livres e fluidas. Ao final, e diante de cada porta, há sempre o novo ou o conhecido". Considerações de P.: Érico se sente forte o suficiente para enfrentar os caminhos possíveis.

Já a Figura 54, que apresenta uma mandala, no caso de Érico, indica uma centralização, sentida como percepção de si mesmo "materializado", mostrando uma evolução na sua relação consigo mesmo.

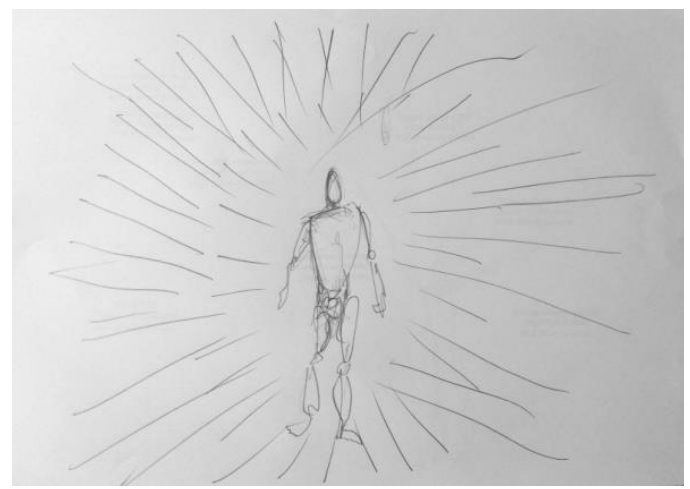

Figura 54. Julho de 2014. Fala de Érico: "me vejo parado, refletindo sobre que caminho seguir. As linhas remetem a luzes ou direções ao redor de meu corpo. Um momento mais concreto, onde me materializo, apresento meu corpo, não somente o meu espírito. Me sinto mais forte com essa verticalidade e solo". Considerações de P.: o homem ao centro da produção está ligado ao mundo exterior pelas linhas ao seu redor; a produção é uma mandala e, como tal, enfatiza a centralização da personalidade. 
As produções do começo de 2014 trouxeram a experiência de estar iluminado e de ter companhia para observar o horizonte. As cores avermelhadas e amareladas sinalizaram vitalidade e calor.

Em maio de 2014, Érico fez uma produção na qual tem que conviver com suas vísceras e expeli-las (Figura 50A). A produção tem uma capa, em que somente uma pequena parte da imagem pode ser visualizada por um buraco. A imagem é intensa e, no momento do atendimento pouca compreensão se lançou sobre ela. A interpretação subjetiva levaria a uma busca de fatores viscerais com os quais Érico deveria se confrontar - essa informação não ficou clara para P. no momento em que apareceu. Em setembro de 2014, Érico teve pleurite crônica, uma doença decorrente de uma inflamação na pleura (membrana que envolve os pulmões). Dada a característica peculiar da produção e sua clara alusão à doença, considerase a hipótese de que a imagem revelou antecipadamente a doença que Érico veio a desenvolver.

Érico faz duas imagens (Figuras 51 e 52): a primeira revela linhas mais retilíneas acima e abaixo e formas mais palpáveis em vermelho e azul ao centro; remete a uma intermediação entre dois mundos, sugerindo uma transição possível a partir do contato entre eles. A produção seguinte traz um caminho livre, sólido, e seguro. Alude ao conhecido, ao ego e à consciência.

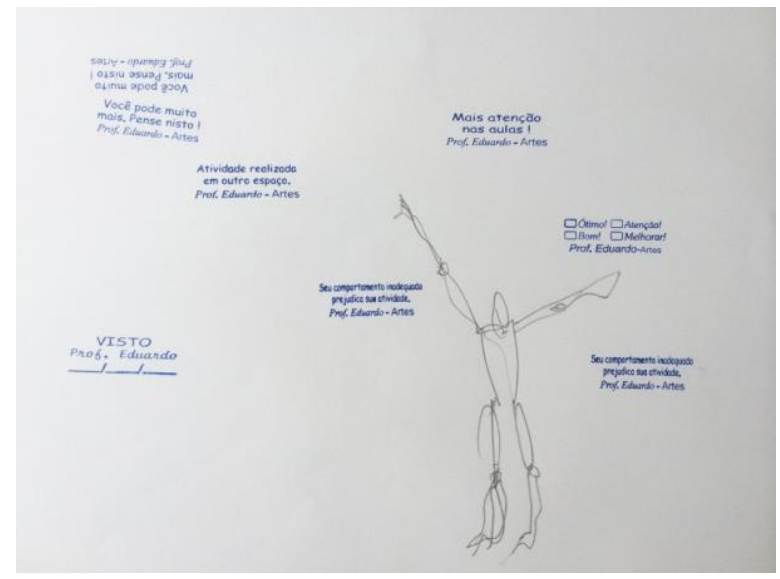

Figura 55. 2014. Fala de Érico: "pedagogia teatral. A figura sou eu. Perdido, repensando o meu papel como educador ou 'louco', diante de valores e de pessoas: pais, crianças, diretores, protagonistas loucos e rotulados, reféns da escolarização e do educar". Considerações de P.: a figura humana, circundada por oito carimbos, "encaixa-se" no espaço possível. A composição contrapõe a pré-formatação dos carimbos à mobilidade e à adequação da figura humana, indicando a flexibilidade necessária à personalidade. 
As relações são fortalecidas e ele coloca limites com mais facilidade. A doença, por sua vez, o leva a pensar no pulmão e em sua simbologia. $O$ pneuma, ou ar, remete à ligação com um dos elementos vitais para a vida. As expressões do arquétipo paterno positivo, como a ampliação da capacidade de discriminação mediante o pensamento, colaboram com a pesquisa simbólica.

A sequência de figuras (Figuras 56-70) sobre anjos revela uma nova possibilidade na vida. P. sugere a natureza de Hermes, capaz de transitar entre mundos, e a de Eros, capaz de fazer ligações amorosas. Érico reconhece em si, nesse momento de vida, uma capacidade rara de ser diplomático em ambiente profissional e não se envolver demasiado com as problemáticas da escola em que leciona. É um momento de fortalecimento da autoestima de Érico; evidencia-se a capacidade de voar, que fora tão almejada por ele no início do processo terapêutico.

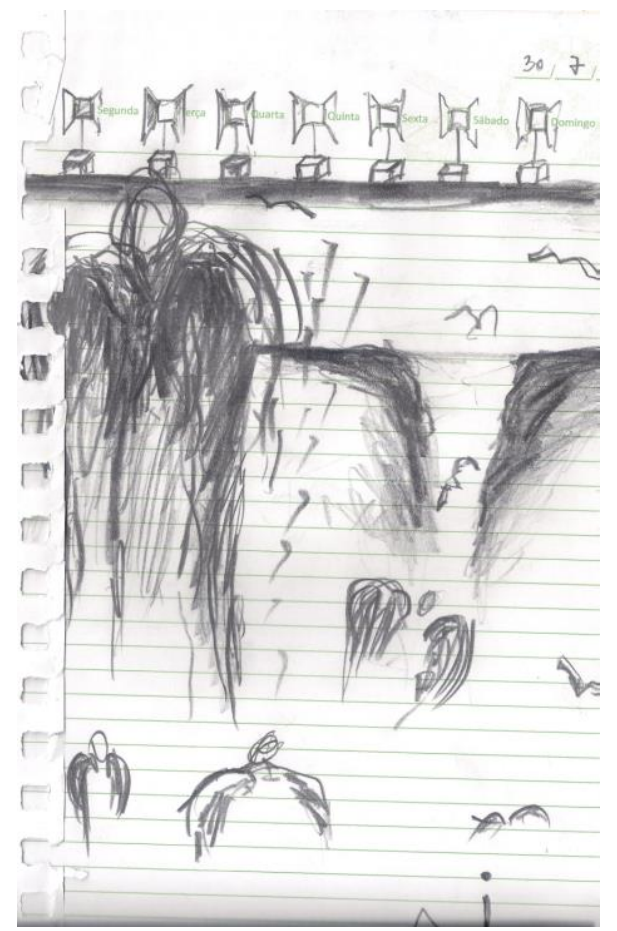

Figura 56. 30 de julho de 2014, primeira da tríade composta pelas Figuras 56, 57 e 58. Fala de Érico: "janelas abertas, mas sem asas com caixas abaixo delas. O convite ao voo, à liberdade e o peso das caixas da alma que não possibilitam um voo. Um imenso anjo observa janelas da alma em terceiro plano e abaixo dele mais anjos menores sobrevoando as passagens das muralhas. Anjos me chamam, sorridentes a voar... sem temer". Considerações de P.: o tema dos anjos revela uma fase em que Érico passeia entre mundos: o da matéria e o do espírito. Essa experiência trouxe adaptação às diferentes dimensões da vida e maleabilidade para transitar entre elas. 


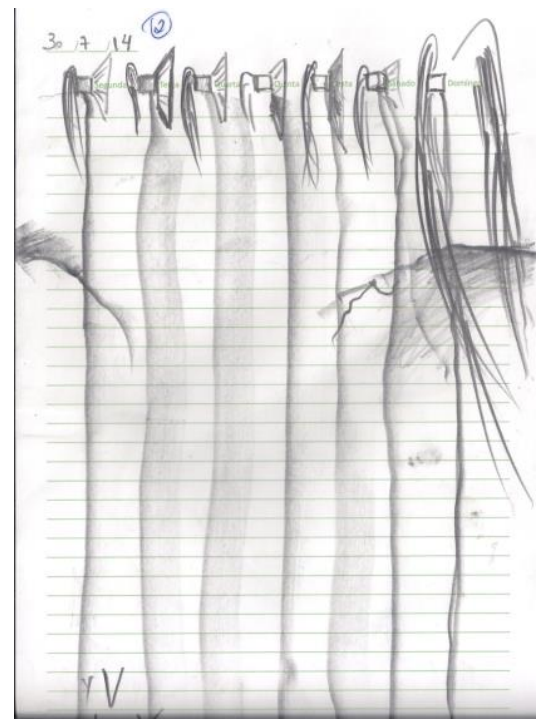

Figura 57. 30 de julho de 2014, segunda da tríade composta pelas Figuras 56, 57 e 58. Fala de Érico: "vales, montanhas ou abismos observados por anjos grandes, além de janelas com asas, lá longe." Considerações de P.: observa-se neste desenho como as distâncias são grandes entre as asas dos anjos grandes e as janelas com asas de anjo. Érico vê vales, montanhas e abismos na produção, o que ofereceu uma ideia das distâncias que passou a percorrer e das dimensões da vida que passou a unir depois de descobrir e se ligar ao seu aspecto anjo.

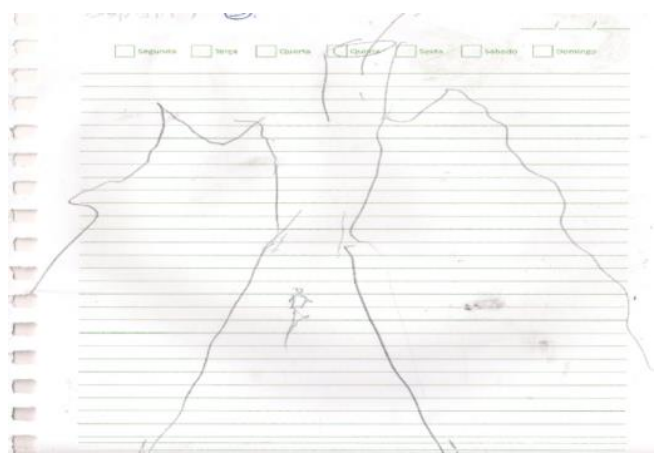

Figura 58. 30 de julho de 2014, terceira da tríade composta pelas Figuras 56, 57 e 58. Fala de Érico: "novamente muralhas, uma passagem e eu entre elas. Pela falta de cor e massa, a imagem é mais leve por ter poucas linhas. Caminhar para mim tem relação com o tempo que passa muito rápido, por isso só caminhar pode não levar a encontrar nada do que se quer, mas, por outro lado, lidamos com o inesperado e podemos sair do padrão e dos referenciais adquiridos". Considerações de P.: Érico busca e tem desejo de viver e ser feliz, mas se assusta com o inesperado e a dimensão do novo em seu caminho. A produção dá uma mostra dessa experiência, quando apresenta a pequenez do homem diante da grandiosidade das muralhas. 


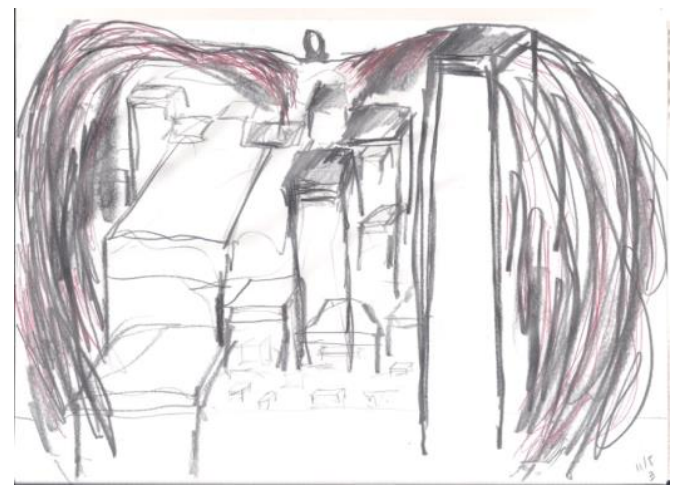

Figura 59. 11 de agosto de 2014. Fala de Érico: "céu e terra. Cubos sólidos de tamanhos diferentes no solo. Asas, uma força maior no entorno acolhendo, protegendo ou abraçando essas formas fortes. Elas estão enraizadas, rígidas no espaço. Eu sou as formas ou o anjo me acolhendo para ser mais flexível comigo mesmo e voar?" Considerações de P.: nesta produção o contraponto entre a matéria e a vida, o estático e o potencial de movimento, são ressaltados. A fala de Érico indica que ele reconheceu que as polaridades pertencem e traduzem conteúdos próprios.

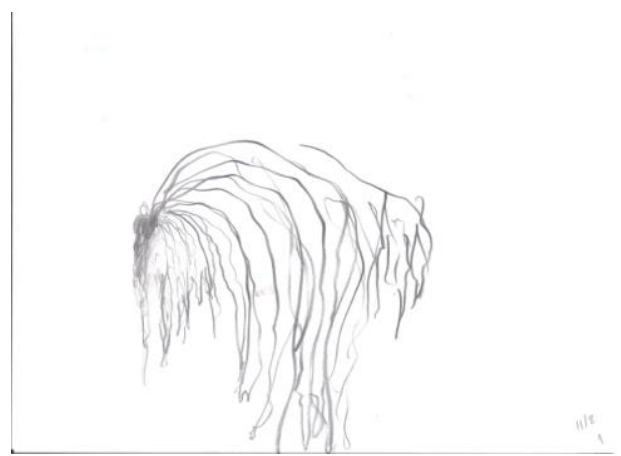

Figura 60. 11 de agosto de 2014. Fala de Érico: "eu com uma asa imensa do meu lado direito. Mas falta a esquerda. Há uma assimetria, um desequilíbrio. Se ter uma asa imensa e forte pode nos dar a sensação de força para voos mais altos, uma única asa não me levanta, não me faz alçar voo. Preciso de outra para avançar. Será que é preciso conquistar, desbravar, viajar com uma única asa? O que será preciso fazer? A realidade pede um tempo e saber lidar com ele vai nos fazer ter a outra asa dentro do possível. O resto para avançar não depende somente de mim". Considerações de P.: a constatação de que há uma assimetria e uma ausência levou Érico à humildade, que estava faltando desde que o símbolo dos anjos apareceu. A doença fez Érico entrar em contato com uma falta, ainda sem sentido exato. 


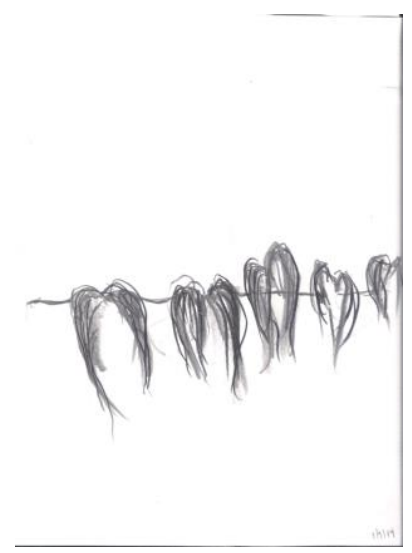

Figura 61. 01 de setembro de 2014. Fala de Érico: "observadores. Asas apoiadas em uma linha. Me sinto observado por elas. Isso é bom, pois parecem serem minhas parceiras para proteção, orientação, bússola e estímulo. Creio que sejam anjos, interlocutores entre o céu e nós, na terra. Com asas posso avançar mais ou recuar. Posso pousar suavemente em solos macios, assim como em pântanos e desertos áridos, e amortecer qualquer acidente". Considerações de P.: nesta produção a prontidão para voar e pousar é assinalada, bem como o fato de que as asas o protegem.

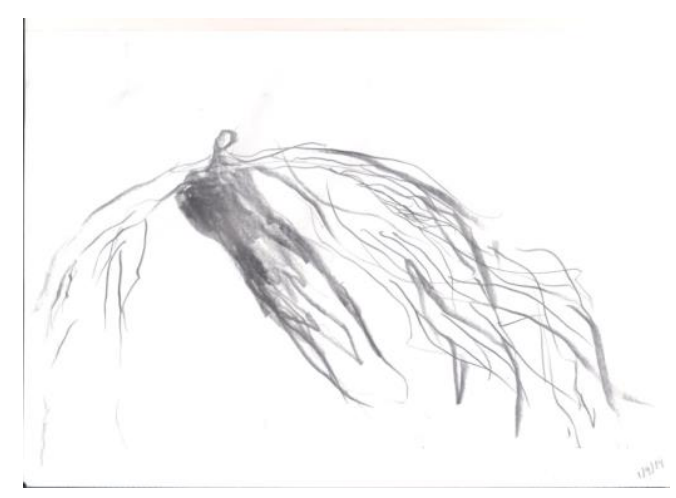

Figura 62. 01 de setembro de 2014. Fala de Érico: "ah, esse voo belo e leve que me traz devaneios. Eu me vejo com uma bela asa forte, imensa e muito leve. Meu corpo está suspenso graças ao impulso dela e da brisa suave que me propulsiona para o encontro das nuvens. De pequeno, menino da terra, já queria voar. Fui um jovem que voou, mas estava sem casca suficiente para enfrentar a vida. Sobrevivi. No momento, me sinto mais maduro, uma sensação jamais sentida. Minhas asas não estão aparadas, nem presas, estão belas e fortes". Considerações de P.: Érico se identifica, no momento, com os anjos e com sua capacidade de voar. Este desenho o revelou. Esta identificação trouxe uma liberdade almejada desde criança, que está sendo vivida intensamente. Para o momento, apenas os aspectos iluminados das asas e dos anjos estão sendo vistos por Érico, em detrimento dos sombrios, presentes em qualquer símbolo. 


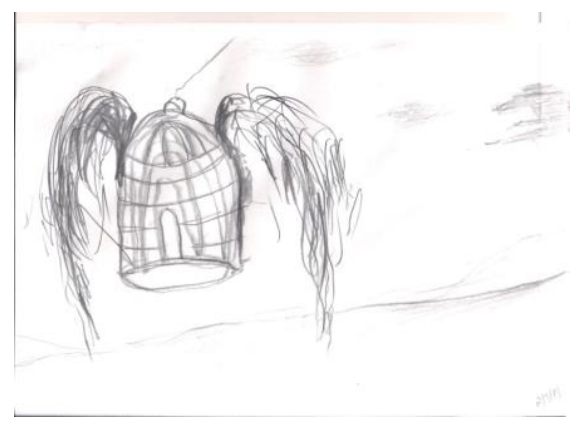

Figura 63. 02 de setembro de 2014. Fala de Érico: "uma gaiola ou jaula com asas a voar. Gaiola ou jaula implica o tigre ou um pássaro. Tanto gaiola como jaula são limitações, espaços limítrofes que impedem a possibilidade de liberdade e do voo. Mas, é simples: colocam-se duas asas e se pode voar mesmo nesses espaços. Tanto o pássaro como o tigre, sensibilidade e agressividade, instinto, fome de se fortalecer como homem, querer romper referências enraizadas na minha formação. Antes. nem se quer voava ou tentava, não vivia. Hoje. sei que posso voar mais ainda, mas entendo que é um processo e estou respeitando o seu tempo". Considerações de P.: mais uma vez o ato de voar relaciona-se com a materialidade. Isto se traduz na proposta verbal de Érico de lidar com suas limitações.

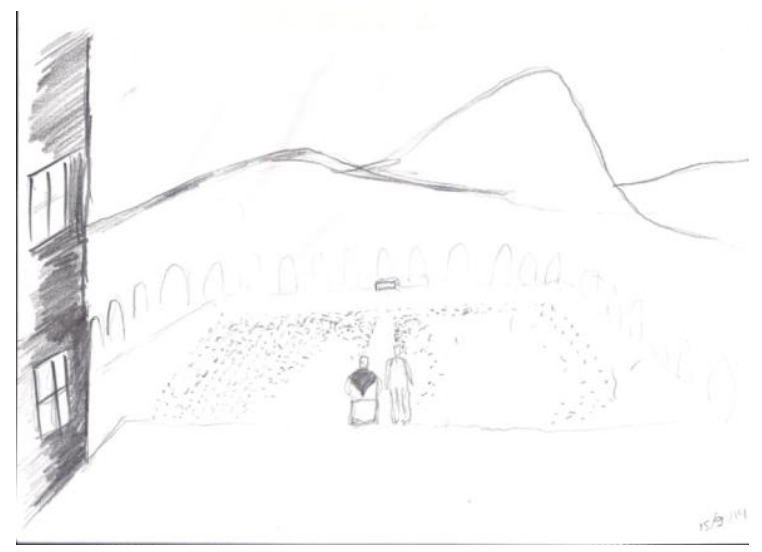

Figura 64. 15 de setembro de 2014. Fala de Érico: "expressão de um sonho. Eu e minha mãe em um terraço da cidade, observando abaixo um imenso templo, com um líder e somente mulheres de xales pretos em seus ombros. Muitas mulheres. Atrás do altar, o cenário era uma grande cadeia de montanhas; não podia descer. Era somente para mulheres. Levei minha mãe até o primeiro degrau da escada, me despedi e observei do terraço sua longa caminhada descendo tantos degraus. Parece um rito de passagem, mudança, despedida. Talvez uma ruptura e libertação minha. Hoje consigo dizer coisas de forma direta e mais assertiva para minha mãe". Considerações de P.: esta produção retrata um sonho em que a mãe, representação básica da experiência materna de Érico desce degraus em direção a um ritual religioso. Esse aspecto de Érico pode se unir a uma dimensão maior e aceitar suas determinações. Tratou-se de uma transformação da experiência do arquétipo materno. 


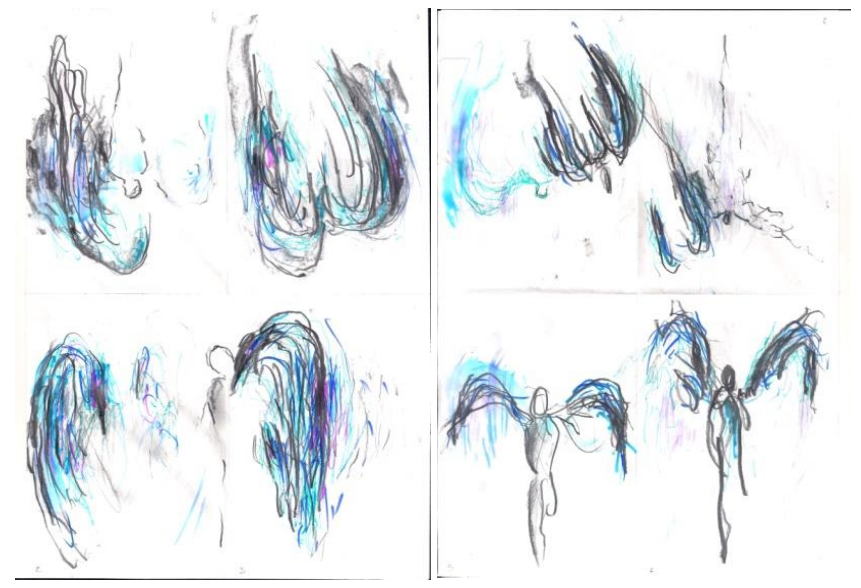

Figuras 65A e 65B. 11 de agosto de 2014. Fala de Érico: "expressão de um sonho. Eu num processo de construção e desconstrução do meu ser. Asas em diferentes momentos (unas, fragmentadas, grandes, voos para cima, quedas). A cor azul minimiza esse processo, suaviza, sem tantas dores e inquietações. As oscilações da vida. Me vejo entre o avançar e recuar. Tenho as asas, mas ainda não sei muito bem como voar e lidar com desafios da época". Considerações de P.: esta produção apresenta oito anjos, em diferentes posições. Expressa possibilidades do aspecto anjo de Érico, embora ele verbalize seus limites.

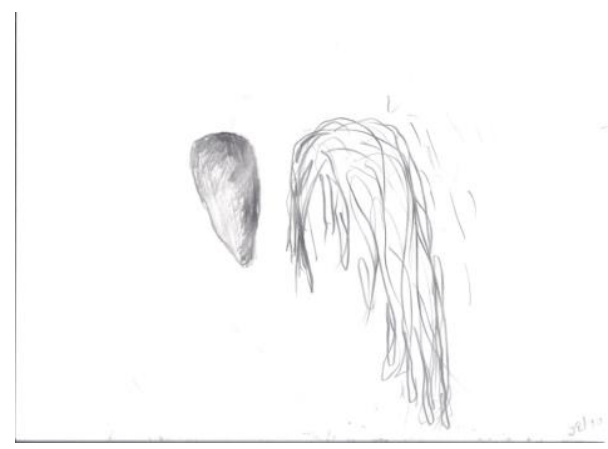

Figura 66. 28 de outubro de 2014. Fala de Érico: "a leveza do peso ou o pesado do leve. Vejo opostos. O maciço de uma forma sombreada e a leveza e fluidez de uma asa e suas linhas. Um par. Uma dupla ou um par? Aqui agrego, do lado, um dos meus pulmões adoecido por um derrame de pleura. Um dos lados do meu pulmão, órgão vital do ar, da respiração, do ritmo, conflita com a fluida e bela asa do outro lado. Desta forma, meu voo foi interrompido. A possibilidade aqui versus a impossibilidade. Ironias da vida?" Considerações de P.: a contraposição entre a asa, leve, e o pulmão, denso, indica polaridades a serem integradas. A doença trouxe à tona um conteúdo denso e fechado que precisa ser integrado à consciência. 
Na vida externa, concreta, Érico conseguiu dizer coisas de forma direta e mais assertiva para sua mãe, sem se sentir prisioneiro de suas determinações.

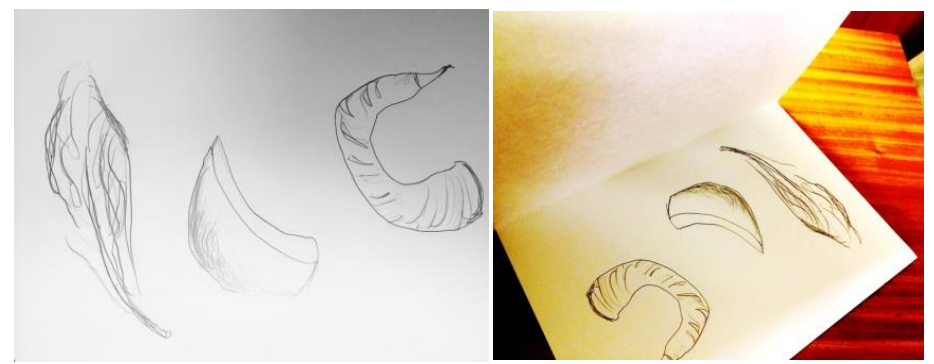

Figuras 67A e 67B. 23 de abril de 2014. Fala de Érico: "linhas fluídas que gradativamente se enrijecem numa metamorfose. A vida contemporânea reforça isso na medida em que temos que sobreviver com nossas cascas". Considerações de P.: aqui a produção se assemelha a cascas, folhas ou raízes. Sinaliza uma passagem do que era abstrato para a materialidade. Curiosamente, as figuras também são feitas em um papel que fecha, tem uma capa (Figura 47B). A aproximação de Érico com o mundo concreto e o desenvolvimento de uma persona, mesmo que inicial, podem estar indicadas pela produção.
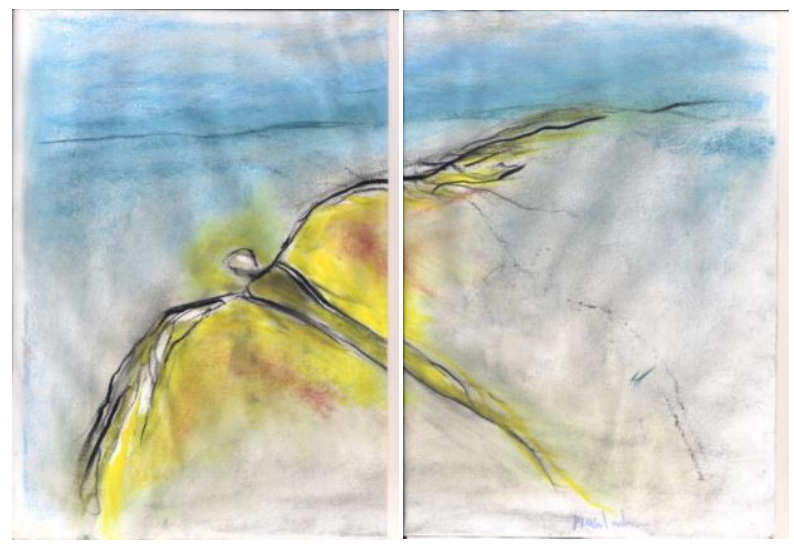

Figuras 68A e 68B . Outubro de 2014. Fala de Érico: "planando. Um voo em total deleite, planando sob um céu límpido e anil. A luz está em meu corpo. Neste voo, meu corpo levita, plana, e senti a leveza de ser e no ser. Um momento que me desprendo de toneladas de sensações ruins, amarguras e medos que passei. Observo de cima o cenário, os desenhos e formas da terra. Vejo as pessoas vivendo, curtindo, e o melhor eu também em êxtase comigo mesmo. Sim. Por mais redundante que seja, voar é ousar e arriscar-se, assim como no viver isto está implícito. Apesar de estar reconstruindo minha vida, muito dela já obtive de 2013 para cá". Considerações de P.: novamente a plenitude do ato de voar é expressa pictórica e verbalmente. Não há indicadores da integração dos conteúdos sombrios que apareceram antes e depois da doença de Érico. 
A produção 69 (Figura 69) apresenta linhas definidas, mas aveludadas, remetem ao pulmão, ao ar, ao expirar, à membrana frágil (pleura). Érico fala do "oco", que é leve, possibilita o voar de forma mais suave. O oco aqui não é o vazio pleno. Hoje há um equilíbrio maior entre as tensões da vida e dos opostos.

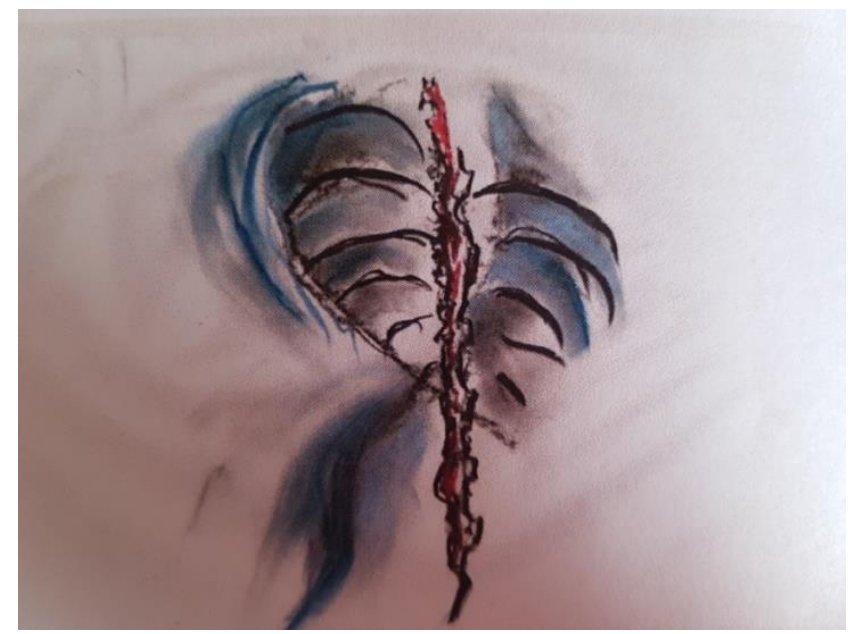

Figura 69. Fala de Érico: "oco". Considerações de P.: esta produção traz as cores azul e preta ligadas ao pulmão, podendo sinalizar uma forma de lidar com suas limitações. Ela relaciona o pulmão, órgão doente de Érico, às asas. O órgão que metaboliza o ar, a pleura, é a parte física afetada de Érico. Há uma relação simbólica entre o ar, espaço adorado por Érico, e o pulmão afetado. É preciso "baixar" à experiência para compreender seus aspectos sombrios e elaborar novas formas de lidar com as dificuldades.

A última produção de Érico (Figura 70) retrata um sonho, onde anjos voam sobre uma mesa; essa situação traz conforto para ele. Érico sente que pode ter a liberdade de transitar por onde quiser. A mesa, relacionada à concretude, já não é mais a única referência para a sua vida. Érico, nesse momento, tem a posse de sua vida psíquica, de sua alma, podendo transitar entre mundos com agilidade e sem sofrimento. 


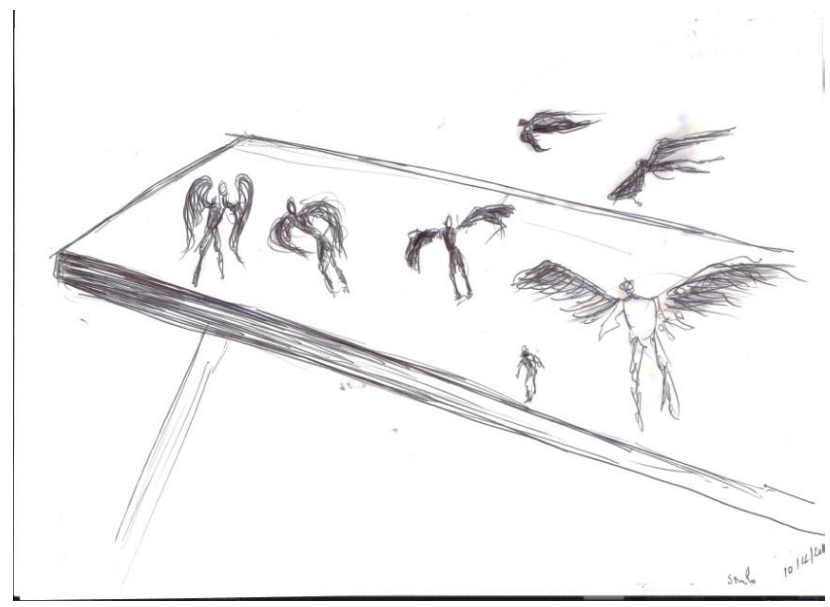

Figura 70. 10 de dezembro de 2014. Fala de Érico: "expressão de um sonho. De cima eu via uma mesa repleta de anjos de tamanhos diferentes, alguns sobre ela, olhando o entorno, outros a sobrevoando e eu bem acima observando algo tão mágico. Pareciam brinquedos, miniaturas. A mesa se movimenta e os anjos não caem, voam. Há uma tensão de opostos, oras figuras imensas, ora minúsculas. Nenhuma desmerece as outras. O minúsculo me remete a aconchego. Nesta imagem não consigo ver nada que seja associado à vida atual. Não sei porque, não me ocorre nada". Considerações de P.: a leveza e a mobilidade dos anjos o protege de cair da mesa, quando ela tomba. Sincronicamente, depois desse sonho, Érico foi demitido dos seus dois empregos, em função do tempo de afastamento para tratar do derrame na pleura. Ele teve que procurar novos trabalhos. Esse sonho e sua compreensão Ihe deram condição de se apoderar de sua força e habilidade para lidar com adversidades.

\section{Hipótese de compreensão psicodinâmica}

Desde o começo dos atendimentos, Érico é empático e cuidadoso no falar. Expressa-se plástica e espontaneamente nas sessões, com desenvoltura. Não deixa dúvidas da sua sensibilidade em relação ao mundo das imagens. As perguntas que repete inúmeras vezes nos primeiros meses de atendimentos são: "por que comigo?", "o que foi que eu fiz de errado?", referindo-se às inúmeras perdas que sofreu e às dificuldades íntimas e pragmáticas que enfrenta.

Érico parece ter desenvolvido uma vida prática bem sucedida durante anos. Nos últimos oito anos, após uma sequência de perdas afetivas e materiais, não consegue reeditar sua vida. Os caminhos antigos não the servem mais e ele não vê nenhuma possibilidade pela frente.

A leitura dos indicadores iniciais oferecidos por Érico sinaliza que o mundo interno não foi valorizado, tampouco investigado, na primeira metade da sua vida. Ele desenvolve uma conduta extrovertida, pautada em suas habilidades, que resulta em êxito do ponto de vista pragmático. Porém, não há um reconhecimento mais amplo de sua vida psíquica, que abranja a 
existência de uma dimensão que ultrapasse seu ego e lance pontes entre os mundos interno e externo.

Érico sofre a ação acentuada de complexos. Sente-se muito ameaçado pelo sentimento de inferioridade e apresenta a marca de complexos materno e paterno negativos e suas consequências no dinamismo psíquico. Pode-se considerá-lo como do tipo puer-dionisíaco, uma pessoa que gosta de seduzir, mas não gosta da rotina e da cobrança. Costuma fugir do compromisso porque se sente abusado, humilhado. $\bigcirc$ complexo revela um misto de pessoa mimada e desvalorizada. É sedutor: ocupa bem a posição de filho protegido. Na estruturação do ego, sua péssima relação com o pai possivelmente o levou à identificação com a mãe. Isso fortalece sua relação com o feminino e fragiliza sua relação com o masculino em si mesmo. Considera-se não só diferente, mas também errado, o "patinho feio" da família. Fica na sombra do sistema familiar, uma situação que é reforçada pelo fato dele ser um trabalhador autônomo, que não ganha muito dinheiro, e por ele ser, possivelmente, homossexual. Érico é sensível e fiel aos vínculos que realiza, apenas demora para confiar neles. Para ele, o exercício intelectual é uma função inferior, que aciona os complexos. Ele toma as falas no sentido concreto e demora um pouco para compreender a dimensão simbólica. Seu desenvolvimento depende do intelecto e da sensação, provavelmente ligados a conteúdos sombrios.

Em função disso, a proposta inicial é a de que Érico entre em contato com seu inconsciente e reconheça sua beleza, amplitude e autonomia, paralelamente, valorizando o que realizou na primeira metade da sua vida. A partir disso, talvez, ele comece a identificar a transitoriedade da vida como natural e o processo que viveu - e vive - como passível de sentido. A conduta terapêutica não responde às perguntas de Érico - que nos lembram dos questionamentos do personagem bíblico Jó -, mas lança olhares para sua história, buscando ampliar sua visão sobre si.

Em "Resposta a Jó", Jung (1986b) discute o Livro de Jó, da Bíblia cristã, à luz da psicologia analítica. Jó é um homem fiel, que busca compreender as ações de Javé, que lhe causam extremo sofrimento. Javé, por sua vez, não reflete - está voltado aos seus próprios interesses. É completo e, como tal, incorpora o bem e o mal. Usando as palavras de Jung, ele incorpora a sua sombra. A tese de Jung é que Jó e Javé sofrem uma evolução após o embate: são obrigados a aumentar os seus níveis de consciência. $\bigcirc$ sofrimento de Jó em relação à Javé assemelha-se ao que se observa em Érico. A partir da experiência com a vida e com seu lado sombrio (que remonta o lado mal de Javé), Érico é obrigado a transformar sua vida e sua consciência. No caso dele, acredita-se que esse caminho se torna criativo, após seu ingresso no tratamento psicoterápico, pois ele passa a olhar e a tratar de si e de sua história de uma nova maneira.

Outra forma de ler o sofrimento de Érico baseia-se na proposição de Hillman (1999). Como puer, Érico não quer ser expulso do Éden. Espera ser plenamente compreendido, confirmado, abençoado e reconhecido em 
virtude do que é e de sua proximidade e intimidade com Deus. Quando isso não acontece, tem a experiência de traição profunda. Esta traição é, contudo, necessária, pois o encaminha a uma nova consciência da realidade. Sair do Éden é iniciar uma nova vida. Nessa visão, a traição não se opõe ao amor, mas está contida no mesmo. Quanto maior o amor, maior a possibilidade de ser traído, uma vez que, esta traição é a condição para a queda do Éden e para o desenvolvimento da personalidade total.

\section{Contratransferência}

P. percebe em Érico um menino machucado e assustado e tem muita empatia por ele. Se há um perigo na contratransferência, é o de P. colocá-lo "no colo", protegê-lo demais. Naturalmente P. compreende sua dor, mas acredita que ele deva tentar sair desse lugar protegido/acomodado que, na verdade, é um lugar de morte, de tortura.

Érico apresenta dificuldade em acreditar na vida, pois se sente desvalorizado "por outros", sempre. Nesse sentido, a função de P. é a de devolver a ele a reponsabilidade de atribuir o seu valor, em vez de esperar isso dos outros. Na contratransferência, sua atitude causa incômodo, tanto pela intensidade do sofrimento, como pelo fato dele se colocar de maneira dependente e impotente. Sua dor é respeitada por P., mas a atitude de se colocar como vítima incapaz nas situações é questionada.

Como Érico sente mais do que pensa, isto é, por ser do tipo sentimento, tem no pensamento sua função inferior. A reflexão é um trabalho sugerido por P.; e, em vez de realizá-lo sozinha, P. faz perguntas que levam Érico a refletir dentro das suas possibilidades. É difícil para ele olhar com distanciamento e identificar nas situações certos mecanismos pautados na lógica. P. costuma apontar isso muitas vezes, sabendo que há dificuldade no distanciamento, pois a ação do complexo toma espaço e nubla, dificultando o pensamento.

\section{Leitura do caso com base nas imagens}

As imagens produzidas por Érico, durante seu processo psicoterápico, e trabalhadas nas sessões, dão margem a inúmeras interpretações e amplificações. São possíveis explorações diversas, extensas e ricas de todas elas. Em função dos limites deste estudo, apenas os conteúdos mais importantes são descritos.

As primeiras imagens produzidas por Érico são basicamente em branco e preto; têm poucas cores. Elas expressam a parte estrutural da psique e mostram a ausência da criança que brinca e os sentimentos de medo de voar e de proteção (fechamento), indicando a ação de um complexo materno negativo.

Algumas das hipóteses de compreensão foram levantadas por P., a partir das respostas de Érico à seguinte indagação: "a partir das suas colocações, você acha que tal imagem pode estar comunicando o que sobre você?". Com 
esse diálogo estabelecido entre P. e Érico, as comunicações do inconsciente foram sendo assimiladas e incorporadas a sua vida consciente.

\section{Considerações finais}

Este trabalho é resultado da união de uma pesquisa sobre o uso de recursos expressivos em psicoterapia com um estudo de caso sob a perspectiva junguiana. A ideia central é demonstrar a coerência existente entre o arcabouço teórico junguiano e $\circ$ uso de recursos expressivos em psicoterapia.

Embora a experiência clínica de diversos analistas revele a riqueza do uso da produção plástica em psicoterapia, e muitos estudiosos embasem na teoria diferentes métodos de aplicação e leitura da expressividade, o tema engendra discussões. Compreendemos que isso se deve, em primeiro lugar, à complexidade da obra de Jung. Diversas são as formas de compreendê-la e também diversos são os métodos de ação, fundamentados na teoria. Soma-se a isso, a riqueza dos recursos expressivos que permitem inúmeros métodos de aplicação.

Este estudo de caso, acompanhado das imagens trabalhadas no processo e de suas interpretações, traduz os movimentos psíquicos, descritos na teoria, com imensa clareza. Considera-se que, em função disso, a expressividade pode enriquecer tanto a prática psicoterapêutica como o estudo e a pesquisa em psicologia analítica. Além disso, o uso de recursos expressivos pode ser um facilitador terapêutico para certas tipologias, multiplicando os recursos dessa abordagem, quando utilizados de maneira cuidadosa e consciente.

\section{Referências}

Abt, T. (2005). Introduction to picture interpretation according to CG Jung. Zurich: Living Human Heritage Publications.

Bach, S. (1990). Life paints its own span: On the significance of spontaneous pictures by severely ill children. Einsiedeln: Daimon.

Bruchon, M. (1972). An expressive modality of personality: Communicative gestures. Bulletin de Psychologie, 26 (1-4), 4-21.

Caligor, L. (1952). The detection of paranoid trends by the Eight Card Redrawing Test (SCRT). Journal of Clinical Psychology, 8(1), 397-401.

Carvalho, M. M. M. F., \& Andrade, L. Q. (1995). Breve histórico do uso da arte em psicoterapia. In M. M. M. F. Carvalho (Coord.). A arte cura? Recursos artísticos em psicoterapia (p. 27-38). Campinas, SP: Editorialpsy II.

Chizzotti, A. (2003). Pesquisa em ciências humanas e sociais. São Paulo: Cortez.

Ciornai, S. (Org.). (2004). Percursos em arteterapia (Coleção Novas Buscas em Psicoterapia, Vol. 62). São Paulo: Summus. 
Conselho Regional de Psicologia (2005). Código de Ética do Psicólogo. São Paulo: CRP. Recuperado em 14 de abril de 2016, de http://www.crpsp.org.br/portal/orientacao/codigo/fr_codigo_etica_new.aspx

Fordham, M. (1957). Reflections in image and symbol. The Journal of Analytical Psychology, 2 (1): 85-92.

Freud, S. (1987). Totem e tabu e outros trabalhos (Coleção Obras Psicológicas Completas de Sigmund Freud, Vol. XIII). Rio de Janeiro: Imago.

Furth, G. M. (2004). O mundo secreto dos desenhos: uma abordagem junguiana da cura pela arte. São Paulo: Paulus.

Hammer, E. F. (1989). Aplicações clínicas dos desenhos projetivos. São Paulo: Casa do Psicólogo.

Hillman, J. (1992). Emotion: A comprehensive phenomenology of theories and their meaning for therapy. Evanston, Illinois: Northwestern University Press.

Hillman, J. (1999). O livro do puer - ensaios sobre o arquétipo do puer aeternus. São Paulo: Paulus.

Jung, C. G. (1975). Memórias, sonhos, reflexões. Rio de Janeiro: Nova Fronteira.

Jung, C. G. (1986a). A natureza da psique. In Obras Completas (Vol. VIII/2). Petrópolis: Ed. Vozes.

Jung, C. G. (1986b). Resposta a Jó. In Obras Completas (Vol. Xl/4). Petrópolis: Ed. Vozes.

Jung, C. G. (1988). Interpretação psicológica do Dogma da Trindade. In Obras Completas (Vol. XI/2). Petrópolis: Ed. Vozes.

Jung, C. G. (1989). Símbolos da transformação. In Obras Completas (Vol. V). Petrópolis: Ed. Vozes.

Jung, C. G. (1990a). Psicogênese das doenças mentais. In Obras Completas (Vol. III). Petrópolis: Ed. Vozes.

Jung, C. G. (1990b). A energia psíquica. In Obras Completas (Vol. VIII/1). Petrópolis: Ed. Vozes.

Jung, C. G. (1991). Psicologia e Alquimia (4a ed.). Petrópolis, RJ: Vozes.

Jung, C. G. (2009). Tipos psicológicos. In Obras Completas (Vol. VI). Petrópolis: Ed. Vozes.

Kolk, V. O. L. (1984). Testes projetivos gráficos no diagnóstico psicológico (Coleção Temas básicos de psicologia, vol. 5). São Paulo: EPU.

Lee, A. (2012). As aventuras de Pi. [DVD]. EUA: 20th Century Fox.

Machover, K. (1949). Proyección de la personalidad en el dibujo de la figura humana. Habana: Cultural.

Naumburg, M. (1955). Art as a symbolic speech. The Journal of Aesthetics and Art Criticism, 13(1), 435-450.

Ramos, D. (2006). A psique do corpo. A dimensão simbólica da doença (3a ed). São Paulo: Summus. 
Samuels, A., Shorter, B., \& Plaut, F. (1988). Dicionário crítico de análise junguiana. Rio de Janeiro: Imago.

Telles, V. S. (2000). A desvinculação do T.A.T. do conceito de "projeção" e a ampliação de seu uso. Psicologia USP, 11 (1): 63-83.

Trinca, W. (1976). Investigação clínica da personalidade: o desenho livre como estímulo de apercepção temática. Belo Horizonte: Interlivros.

Vasconcelos, E. A., \& Giglio, J. S (2006). Arte na psicoterapia: imagens simbólicas em psico-oncologia. São Paulo: Vetor.

Whitmont, E. (2002). A busca do símbolo. São Paulo: Cultrix, 2002.

Minicurrículo: Paola Vieitas Vergueiro - Analista em formação pelo Instituto Junguiano de São Paulo (IJUSP). Doutora em Psicologia Clínica pelo Núcleo de Estudos Junguianos da Pontifícia Universidade Católica de São Paulo (PUC$\mathrm{SP})$; mestre em Distúrbios do Desenvolvimento pelo Instituto Mackenzie; especialista na abordagem junguiana pela PUC-SP; graduada em Psicologia pela PUC-SP; arteterapeuta formada pela Associação de Arteterapia do Estado de São Paulo. Psicóloga, psicoterapeuta, professora, orientadora e supervisora. Desenvolve pesquisas dedicadas à interface entre psicologia analítica, arte, sociedade e cultura.E-mail: paola.vv@hotmail.com 